\title{
Late-Paleozoic emplacement and Meso-Cenozoic reactivation of the southern Kazakhstan granitoid basement
}

\author{
Elien De Pelsmaeker a,*, Stijn Glorie ${ }^{\mathrm{b}}$, Mikhail M. Buslov c,d ${ }^{\mathrm{c}}$, Fedor I. Zhimulev ${ }^{\mathrm{c}}$, Marc Poujol ${ }^{\mathrm{e}}$, \\ Valeriy V. Korobkin ${ }^{f}$, Frank Vanhaecke ${ }^{g}$, Evgeny V. Vetrov ${ }^{\mathrm{c}}$, Johan De Grave ${ }^{\mathrm{a}}$ \\ ${ }^{a}$ Department of Geology and Soil Science, Ghent University, Ghent, Belgium \\ b Tectonics, Resources and Exploration (TraX), Department of Earth Sciences, University of Adelaide, Adelaide, Australia \\ c Institute of Geology E' Mineralogy, Siberian Branch, Russian Academy of Sciences, Novosibirsk, Russia \\ d Novosibirsk State University, Novosibirsk, Russia \\ e Université de Rennes 1, Laboratoire Géosciences Rennes, UMR 6118 CNRS, Rennes, France \\ ${ }^{\mathrm{f}}$ Department of Geology and Physics of the Earth, Kazakh-British Technical University, Almaty, Kazakhstan \\ ${ }^{g}$ Department of Analytical Chemistry, Ghent University, Ghent, Belgium
}

\section{A R T I C L E I N F O}

\section{Article history:}

Received 21 November 2014

Received in revised form 30 April 2015

Accepted 1 June 2015

Available online 24 June 2015

\section{Keywords:}

Ili-Balkhash

Zircon U-Pb dating

Apatite fission track thermochronology

Junggar

Tien Shan

Dzhungar

\begin{abstract}
A B S T R A C T
The Ili-Balkhash Basin in southeastern Kazakhstan is located at the junction of the actively deforming mountain ranges of western Junggar and the Tien Shan, and is therefore part of the southwestern Central Asian Orogenic Belt. The basement of the Ili-Balkhash area consists of an assemblage of mainly Precambrian microcontinental fragments, magmatic arcs and accretionary complexes. Eight magmatic basement samples (granitoids and tuffs) from the Ili-Balkhash area were dated with zircon U-Pb LA-ICP-MS and yield Carboniferous to late Permian ( 350-260 Ma) crystallization ages. These ages are interpreted as reflecting the transition from subduction to (post-) collisional magmatism, related to the closure of the Junggar-Balkhash Ocean during the Carboniferousearly Permian and hence, to the final late Paleozoic accretion history of the ancestral Central Asian Orogenic Belt. Apatite fission track (AFT) dating of 14 basement samples (gneiss, granitoids and volcanic tuffs) mainly provides Cretaceous cooling ages. Thermal history modeling based on the AFT data reveals that several intracontinental tectonic reactivation episodes affected the studied basement during the late Mesozoic and Cenozoic. Late Mesozoic reactivation and associated basement exhumation is interpreted as distant effects of the Cimmerian collisions at the southern Eurasian margin and possibly of the Mongol-Okhotsk Orogeny in SE Siberia during the Jurassic-Cretaceous. Following tectonic stability during the Paleogene, inherited basement structures were reactivated during the Neogene (constrained by Miocene AFT ages of 17-10 Ma). This late Cenozoic reactivation is interpreted as the far-field response of the India-Eurasia collision and reflects the onset of modern mountain building and denudation in southeast Kazakhstan, which seems to be at least partially controlled by the inherited basement architecture.
\end{abstract}

(c) 2015 Elsevier B.V. All rights reserved.

\section{Introduction}

The Ili-Balkhash Basin (IBB) is a Meso-Cenozoic foreland basin to the growing Tien Shan and West Junggar orogens, situated in SE Kazakhstan (Fig. 1). It is separated from the Chinese Junggar Basin (E) by the Kazakh-Chinese West Junggar Mountains and continues southeast in the Chinese Ili Basin (Fig. 1). To the west, the basin is bounded by the vast Kazakhstan paleocontinent and to the northeast, at the border zone with Siberia, by the Altai-Sayan Mountains (Fig. 1). The Trans-Ili

\footnotetext{
* Corresponding author at: Department of Geology and Soil Science, Ghent University, Krijgslaan 281.S8, WE13, B-9000 Gent, Belgium.

E-mail address: Elien.DePelsmaeker@UGent.be (E. De Pelsmaeker).
}

and Kungey mountain ranges are part of the Kazakh-Kyrgyz Tien Shan and separate the IBB from the intramontane Issyk-Kul Basin to the south (Fig. 2).

The IBB is located in the southwestern part of the Central Asian Orogenic Belt (CAOB) (Fig. 1). The CAOB represents one of the largest Phanerozoic accretionary orogens in the world and stretches from North China-Tarim, through Kazakhstan to the Siberian craton (Korobkin and Buslov, 2011; Sengör et al., 1993; Windley et al., 2007). The CAOB can be regarded as a complex collage of different terranes: mainly fragments of microcontinents, arc and accretionary complexes. These were amalgamated during several Paleozoic accretion-collision events, and associated magmatic episodes, in relation to the closure of the PaleoAsian Ocean (e.g. Alexeiev et al., 2011; Buslov, 2011; Dobretsov and Buslov, 2007; Filippova et al., 2001; Korobkin and Buslov, 2011; Wilhem et al., 2012; Windley et al., 2007; Xiao et al., 2013). Final 


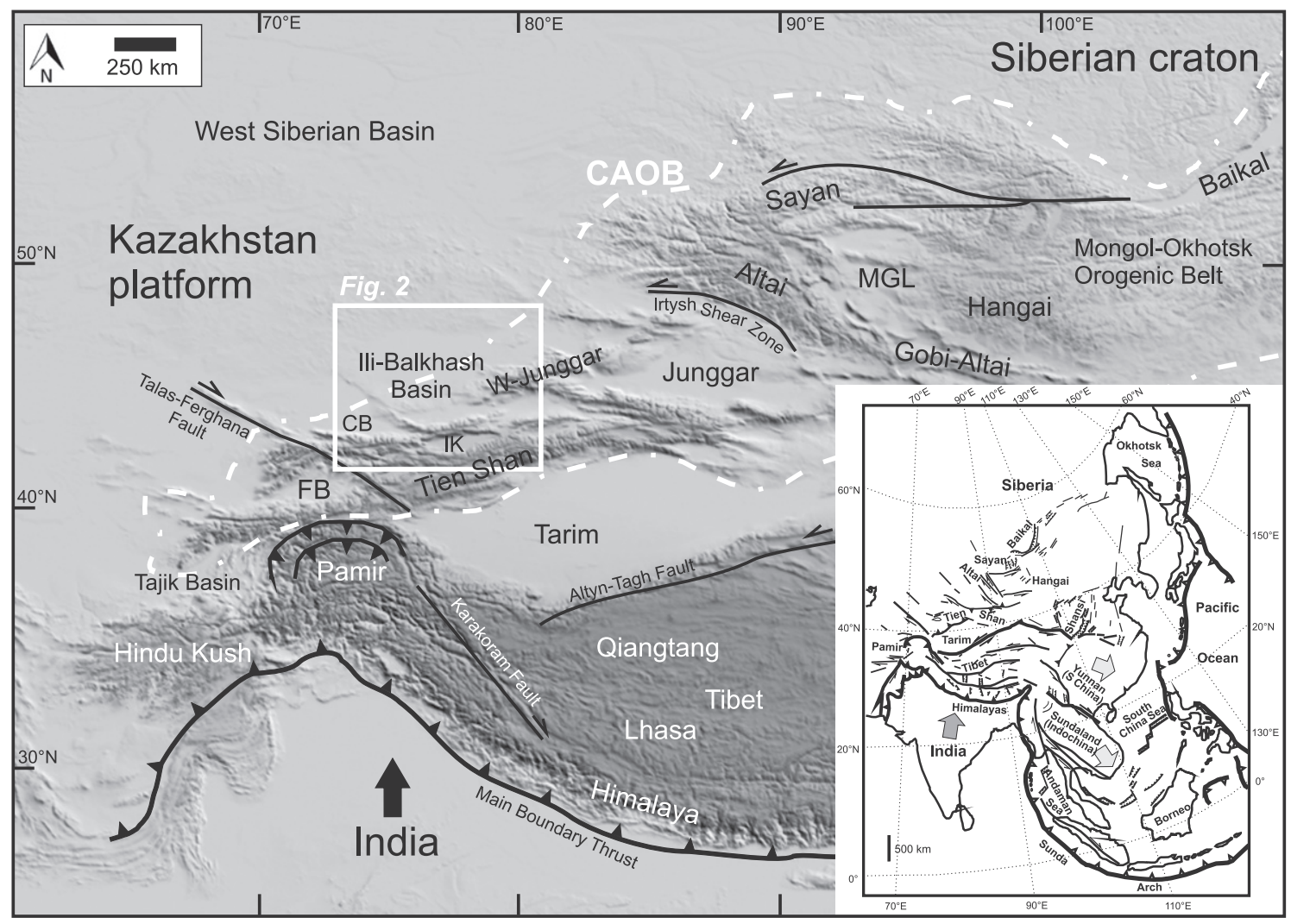

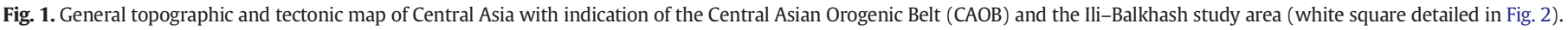
$\mathrm{CB}=$ Chu Basin, FB = Ferghana Basin, IK = Issyk-Kul Basin, MGL = Mongolian Great Lakes, W-Junggar = West Junggar Mountains.

amalgamation of the CAOB took place in the Permian and was accompanied by significant (post-) collisional tectonic and magmatic activity (e.g. B. Wang et al., 2009; Wilhem et al., 2012). During the Mesozoic and Cenozoic, parts of the CAOB were periodically reactivated in response to distal tectonic events, with a final (and still active) late Cenozoic shortening phase related to the India-Eurasia collision (e.g. De Grave et al., 2007; Dumitru et al., 2001; Jolivet et al., 2010). Hence, as a consequence of the large-scale reactivation of the CAOB, the presentday topography is dominated by intracontinental mountain ranges (mainly consisting of deformed Precambrian and Paleozoic basement) separated by intramontane and foreland basins which are mainly characterized by Meso-Cenozoic sedimentary deposits.

Although absolute radiometric age information on the surrounding (mainly basement) area, i.e. the Kyrgyz Tien Shan (e.g. Bullen et al., 2001; De Grave et al., 2011a, 2012, 2013; Glorie et al., 2010, 2011b; Konopelko et al., 2007; Macaulay et al., 2014), the Chinese Junggar (e.g. Hendrix et al., 1992; Shen et al., 2012; Zhou et al., 2008) and the southern Altai (e.g. Glorie et al., 2011a, 2012a, 2012b; Tong et al., 2014) has augmented our knowledge of the broader region, still little is known about the geodynamic evolution of the IBB, and absolute age data from the border zone of the aforementioned terranes is lacking. In this perspective, we present twenty-two new ages (8 zircon $\mathrm{U}-\mathrm{Pb}$ and 14 apatite fission-track ages) from basement samples collected around the IBB in SE Kazakhstan. Sampled basement ranges include the adjacent Kazakh West Junggar (or Dz(h)ungarian), Trans-Ili (or Zailisky), Zhetyzol and Chu-Ili mountains (Fig. 2). The results will be placed in a broader geodynamic framework based on available data in order to gain a better understanding of the thermo-tectonic history of the southeastern Kazakh basement with the future aim of constraining provenance indicators for Meso-Cenozoic sediment sources in the IBB.

\section{Geological setting}

The IBB is located at the southeastern edge of Kazakhstan, at the junction of the Kazakh-Chinese West Junggar Mountains and the Kyrgyz-Chinese Tien Shan, which are part of the southwestern CAOB (Figs. 1 and 2). The West Junggar Mountains form the southwestern boundary of the triangular-shaped Junggar Basin and are largely composed of Paleozoic magmatic arcs and accretionary complexes that amalgamated during the late Paleozoic (Korobkin and Buslov, 2011; Shen et al., 2012; Xiao et al., 2008). Our study area partly encompasses the Kazakh West Junggar Mountains, which can be viewed as the westward topographic continuation of the Chinese West Junggar Mountains, more or less west of the Junggar Fault (Fig. 2).

The currently reactivated intracontinental Tien Shan orogen extends from West to East through Uzbekistan, Kazakhstan, Tajikistan, Kyrgyzstan and China (Xinjiang province) over a distance of more than $2000 \mathrm{~km}$ (Fig. 1). The Tien Shan is subdivided in different tectonic units, but cross-boundary correlation and nomenclature through the aforementioned countries is often not uniform. Traditionally, the western Tien Shan (post-Soviet states) is divided into three tectonic units: the North Tien Shan (NTS), Middle Tien Shan (MTS) and South Tien Shan (STS) units (e.g. Biske et al., 2013; De Grave et al., 2012, 2013; Glorie et al., 2010, 2011b; Seltmann et al., 2011) (Fig. 2). The NTS mainly consists of Precambrian microcontinental fragments, intruded by early Paleozoic granitoids (Glorie et al., 2010; Korobkin and Buslov, 2011) (Fig. 3). The MTS basement is mainly composed of Precambrian crust, covered with early-middle Paleozoic sediments and intercalations of late Paleozoic granitoids (De Grave et al., 2013; Konopelko et al., 2007; Seltmann et al., 2011). The STS represents a late Paleozoic accretionary complex, related to the collision of paleo-Kazakhstan with Tarim during the late Paleozoic (Glorie et al., 2011b; Konopelko et al., 2007; Seltmann 


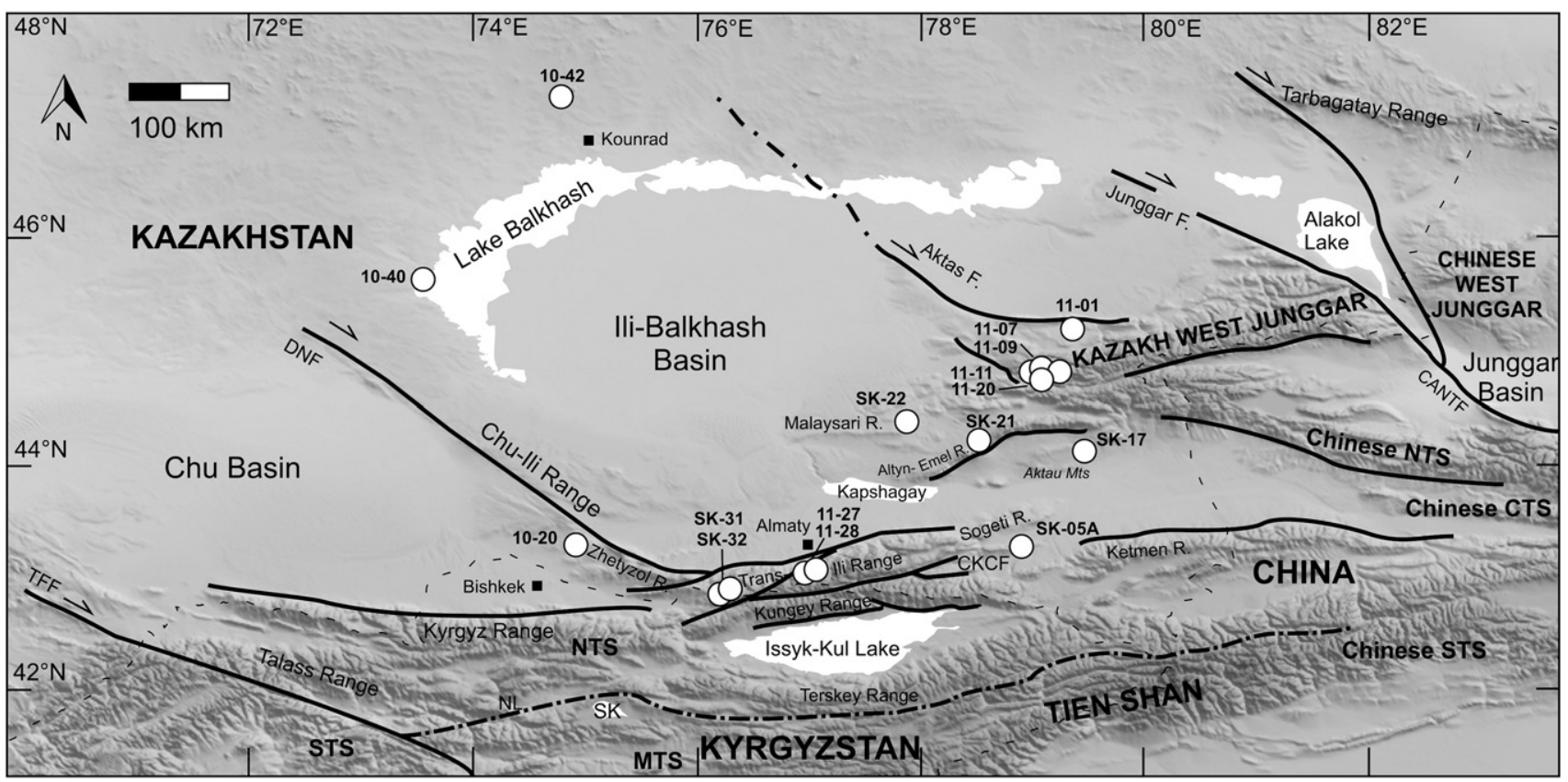

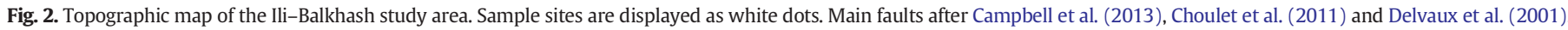

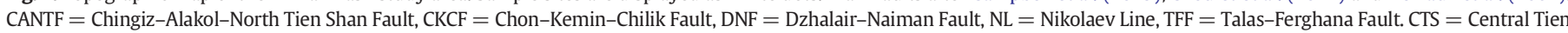
Shan, MTS = Middle Tien Shan, NTS = North Tien Shan, STS = South Tien Shan. F. = Fault, Mts = Mountains, R. = Range, SK = Song Kul lake

et al., 2011). Our study area is situated along the northern edge of the Kyrgyz NTS terrane, which can be continued eastwards to the Chinese North and Central Tien Shan assemblage (Fig. 2). The latter can be considered as an amalgamated unit existing of Precambrian continental fragments, Paleozoic island arcs and accretionary complexes (Biske et al., 2013; Han et al., 2011; Xiao et al., 2013). The detailed correlation between the Kyrgyz and Chinese Tien Shan units is still a matter of debate (e.g. Biske et al., 2013; Xiao et al., 2010, 2013) and falls beyond the scope of this paper.

\subsection{Paleozoic amalgamation of the Kazakhstan paleocontinent}

During the early Paleozoic, the paleo-Kazakhstan basement assemblage was formed by successive amalgamations of Precambrian microcontinents (likely of an Eastern Gondwana origin), and Cambrian to early Silurian island arcs (Dobretsov and Buslov, 2007; Windley et al., 2007). These numerous early Paleozoic accretion-collision events and associated magmatic episodes gave rise to the formation of the Kazakhstan paleocontinent by the late Silurian (Alexeiev et al., 2011; Bazhenov et al., 2012; Biske et al., 2013; Filippova et al., 2001; Korobkin and Buslov, 2011; Wilhem et al., 2012; Windley et al., 2007; Xiao et al., 2010; Zhao and He, 2013). As a result, early Paleozoic granitoids associated with the collision-accretion events constructing the Kazakhstan paleocontinent, can be found across the Kazakhstan and NTS basement (e.g. De Grave et al., 2013; Degtyarev, 2011; Degtyarev et al., 2006; Glorie et al., 2010; Korobkin and Buslov, 2011) (Fig. 3).

Following its amalgamation, the Kazakhstan paleocontinent remained emerged during most of the Silurian and early Devonian, and drifted northwards until the Permian (Wilhem et al., 2012; Windley et al., 2007). During the middle and late Paleozoic, the paleocontinent was isolated from Siberia, Europa and Tarim, and surrounded by the Ob-Zaisan (NW), Uralia (SW), Turkestan (SE) and Junggar-Balkhash (NE) oceans (e.g. Filippova et al., 2001; Korobkin and Buslov, 2011; Windley et al., 2007) (Fig. 3b). These oceans are considered as subbasins of the Paleo-Asian Ocean. The ensuing tectonic history of the Kazakh paleocontinent is then dominated by the closure of the aforementioned ocean basins and the associated Siberia-paleo-KazakhstanTarim convergence. Subduction of the Junggar-Balkhash oceanic lithosphere beneath the northeastern margin of the Kazakhstan paleocontinent started in the early Devonian, resulting in a major Andean-type magmatic belt (Windley et al., 2007) (Fig. 3). By the Late Devonian, the subduction zone moved eastwards and arc magmatism continued in the Ili-Balkhash region until the late Carboniferousearliest Permian (Filippova et al., 2001; Korobkin and Buslov, 2011; Kröner et al., 2008; Seltmann et al., 2011; Wilhem et al., 2012; Windley et al., 2007; Xiao et al., 2013). Simultaneously, to the southeast of the paleocontinent, oblique closure of the Turkestan Ocean took place from the late Carboniferous until the early Permian and resulted in the collision between Kazakhstan and Tarim (Fig. 3c). Related to the general convergent motion between Tarim and Siberia, with Kazakhstan trapped in between, Devonian-early Mesozoic oroclinal bending of the Kazakhstan paleocontinent occurred (e.g. Abrajevitch et al., 2007, 2008; Choulet et al., 2011; Levashova et al., 2007, 2012; Van der Voo et al., 2006). In addition, closure of the Ob-Zaisan and Uralian oceans led to the final collision between paleo-Kazakhstan and Siberia and Baltica respectively (Fig. 3b-c), resulting in the gradual consumption of surrounding oceanic lithosphere and final amalgamation of the ancestral CAOB by the late Permian (e.g. Buslov et al., 2004, 2013; Windley et al., 2007). More details about the geodynamic evolution of paleo-Kazakhstan during the Paleozoic can be found in e.g. (Korobkin and Buslov, 2011).

\subsection{Latest Paleozoic to Cenozoic intracontinental evolution}

Since the final incorporation of the Kazakhstan paleocontinent in paleo-Eurasia during the Permian, its geodynamic evolution has been dominated by intracontinental tectonics. During the late Permianearly Mesozoic, the Kazakhstan orocline became completely closed and the area was affected by (1) (post-) collisional deformation and large-scale strike-slip faulting (e.g. the Talas-Ferghana Fault, Fig. 1) related to the relative motions of Baltica, Siberia, Junggar and Tarim, and (2) tectonic far-field effects of collisions transpiring at the plate's margins several hundreds of kilometers away (Abrajevitch et al., 2008; Buslov, 2011; Buslov et al., 2003b, 2004; Choulet et al., 2011; Levashova et al., 2012; Rolland et al., 2013; Sengör and Natal'in, 1996; Van der Voo et al., 2006; Wilhem et al., 2012; Windley et al., 2007). 

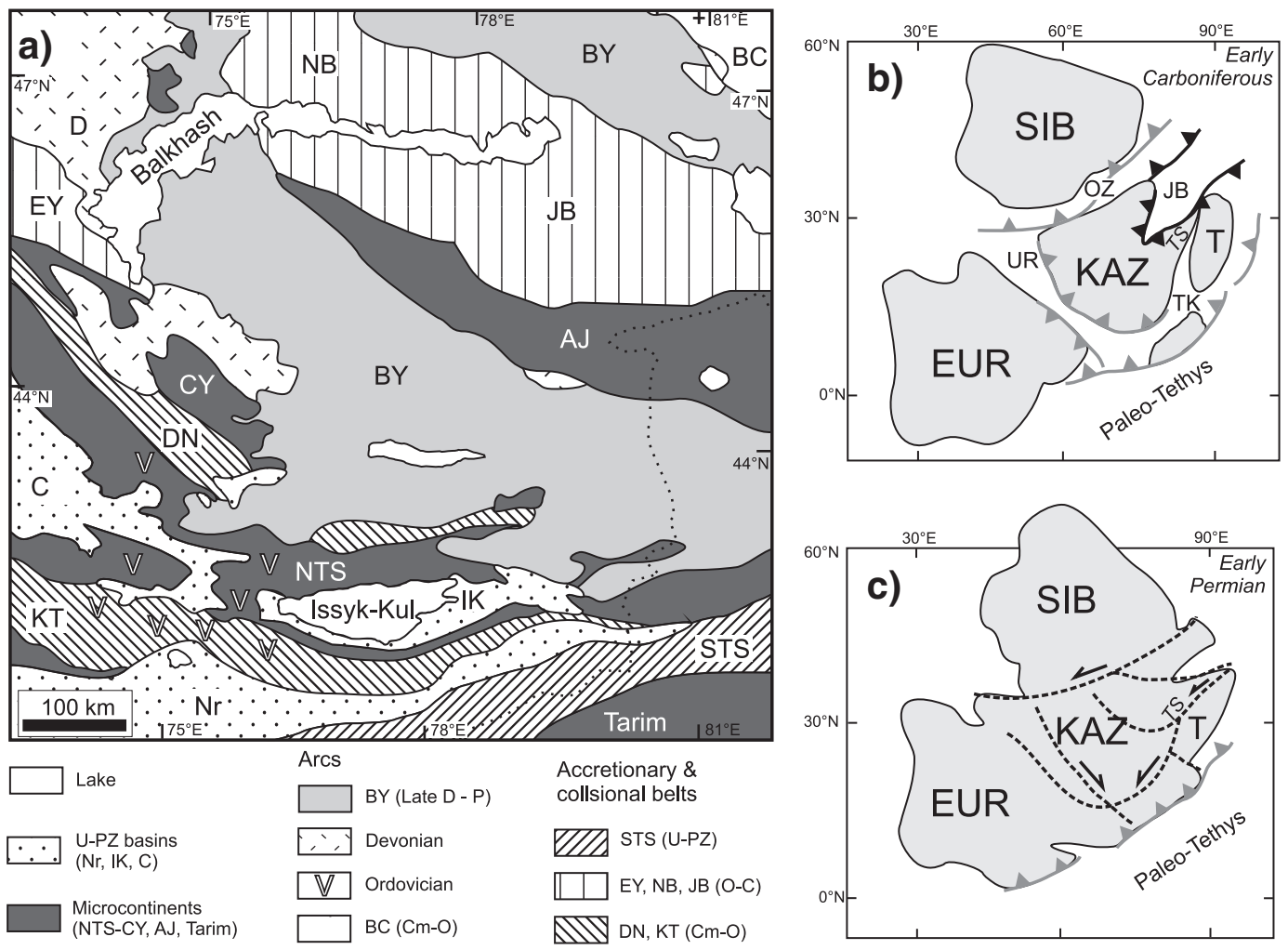

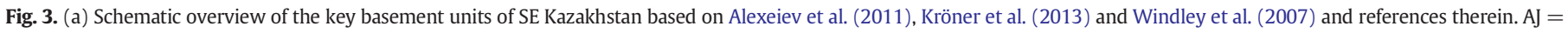

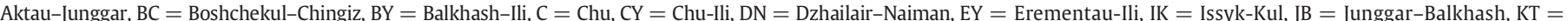

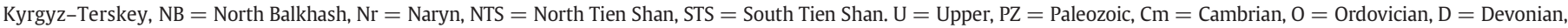

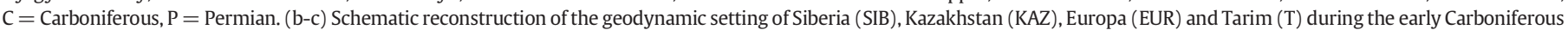

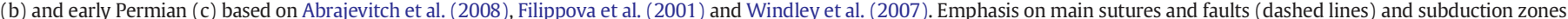

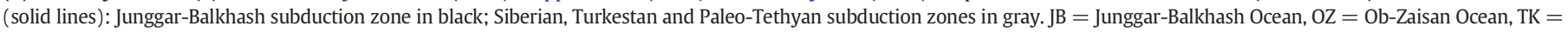
Turkestan Ocean, UR = Uralian Ocean, TS = Tien Shan.

Also during the Permian, the type of magmatism changed from a collisional to a post-collisional setting (e.g. Biske et al., 2013; Kröner et al., 2008; Windley et al., 2007; Zhao and He, 2013). Traces of this post-collisional magmatic episode (mainly A-type and (per-)alkaline magmatism) can be found in e.g. the Kyrgyz North Tien Shan (De Grave et al., 2013; Kröner et al., 2008), the Chinese Central Tien Shan (Dong et al., 2011), the Chinese West Junggar (Shen et al., 2013a) and southern Altai (Tong et al., 2014).

During the latest Paleozoic-Mesozoic, the CAOB was repeatedly reactivated as a distant effect related to the closure of the PaleoTethys and/or Mongol-Okhotsk oceans (e.g. De Grave et al., 2013;
Jolivet, in press; Jolivet et al., 2010, 2013b). Evidence for these reactivation episodes is often documented in the cooling histories of the exhumed basement rocks and in the sediments of the intervening basins, but the extent of these reactivation events is still under discussion (e.g. De Grave et al., 2007; Dumitru et al., 2001; Glorie and De Grave, in press; Jolivet et al., 2013a,b; Vandoorne et al., 2011; Yang et al., 2015). Due to the closure of the Paleo-Tethys Ocean, several accretion-collision events took place at the southern Eurasian margin resulting in the creation of the Mesozoic Tien Shan (e.g. De Grave et al., 2013; Dumitru et al., 2001; Jolivet, in press; Yang et al., 2013). These events are often grouped as the Cimmerian Orogeny and include

Table 1

Sample localities, lithology and used methods. AFT = Apatite Fission-Track dating, ZUPb $=$ zircon U-Pb dating.

\begin{tabular}{|c|c|c|c|c|c|c|}
\hline Sample & Latitude $(\mathrm{N})$ & Longitude (E) & Alt. (m) & Sample site & Lithology & Method \\
\hline $11-01$ & $45^{\circ} 16^{\prime} 25.5^{\prime \prime}$ & $079^{\circ} 20^{\prime} 49.0^{\prime \prime}$ & 1000 & Kazakh West Junggar Range & Granite & $\mathrm{AFT}$ and $\mathrm{ZUPb}$ \\
\hline $11-07$ & $44^{\circ} 53^{\prime} 39.3^{\prime \prime}$ & $079^{\circ} 01^{\prime} 56.9^{\prime \prime}$ & 1718 & Kazakh West Junggar Range & Diorite & AFT and $\mathrm{ZUPb}$ \\
\hline $11-09$ & $44^{\circ} 53^{\prime} 36.1^{\prime \prime}$ & $079^{\circ} 09^{\prime} 38.1^{\prime \prime}$ & 1763 & Kazakh West Junggar Range & Diorite & AFT and ZUPb \\
\hline $11-11$ & $44^{\circ} 53^{\prime} 05.9^{\prime \prime}$ & $078^{\circ} 58^{\prime} 42.1^{\prime \prime}$ & 2029 & Kazakh West Junggar Range & Diorite & AFT \\
\hline $11-20$ & $44^{\circ} 53^{\prime} 05.9^{\prime \prime}$ & $078^{\circ} 58^{\prime} 42.1^{\prime \prime}$ & 2029 & Kazakh West Junggar Range & Granite & AFT and $\mathrm{ZUPb}$ \\
\hline SK-17 & $44^{\circ} 14^{\prime} 35.0^{\prime \prime}$ & $079^{\circ} 28^{\prime} 16.3^{\prime \prime}$ & 1168 & Altyn-Emel Range & Tuff & $\mathrm{ZUPb}$ \\
\hline SK-21 & $44^{\circ} 11^{\prime} 07.4^{\prime \prime}$ & $078^{\circ} 32^{\prime} 25.3^{\prime \prime}$ & 1542 & Altyn-Emel Range & Granodiorite & AFT and $\mathrm{ZUPb}$ \\
\hline SK-22 & $44^{\circ} 28^{\prime} 44.1^{\prime \prime}$ & $077^{\circ} 55^{\prime} 38.8^{\prime \prime}$ & 930 & Malaysari Range & Tuff & $\mathrm{ZUPb}$ \\
\hline $11-27$ & $43^{\circ} 03^{\prime} 21.5^{\prime \prime}$ & $076^{\circ} 58^{\prime} 59.2^{\prime \prime}$ & 2510 & Trans-Ili Range & Diorite & AFT \\
\hline $11-28$ & $43^{\circ} 02^{\prime} 22.3^{\prime \prime}$ & $076^{\circ} 56^{\prime} 40.0^{\prime \prime}$ & 3379 & Trans-Ili Range & Granite & AFT \\
\hline SK-31 & $42^{\circ} 54^{\prime} 54.0^{\prime \prime}$ & $076^{\circ} 13^{\prime} 05.2^{\prime \prime}$ & 3076 & Trans-Ili Range & Gneiss & AFT \\
\hline SK-32 & $42^{\circ} 55^{\prime} 10.2^{\prime \prime}$ & $076^{\circ} 13^{\prime} 00.7^{\prime \prime}$ & 3357 & Trans-Ili Range & Gneiss & AFT \\
\hline SK-05A & $43^{\circ} 20^{\prime} 24.0^{\prime \prime}$ & $078^{\circ} 56^{\prime} 01.6^{\prime \prime}$ & 1337 & Sogeti Range & Granite & $\mathrm{AFT}$ and $\mathrm{ZUPb}$ \\
\hline $10-20$ & $43^{\circ} 19^{\prime} 38.1^{\prime \prime}$ & $074^{\circ} 51^{\prime} 57.0^{\prime \prime}$ & 904 & Zhetyzol Range & Granite & AFT \\
\hline $10-40$ & $45^{\circ} 42^{\prime} 31.5^{\prime \prime}$ & $073^{\circ} 30^{\prime} 20.4^{\prime \prime}$ & 344 & Near Priozersk (W of Lake Balkhash) & Granite & AFT \\
\hline $10-42$ & $47^{\circ} 21^{\prime} 39.3^{\prime \prime}$ & $074^{\circ} 44^{\prime} 18.2^{\prime \prime}$ & 576 & Bektauta mountain ( $\mathrm{N}$ of Lake Balkhash) & Granite & AFT \\
\hline
\end{tabular}




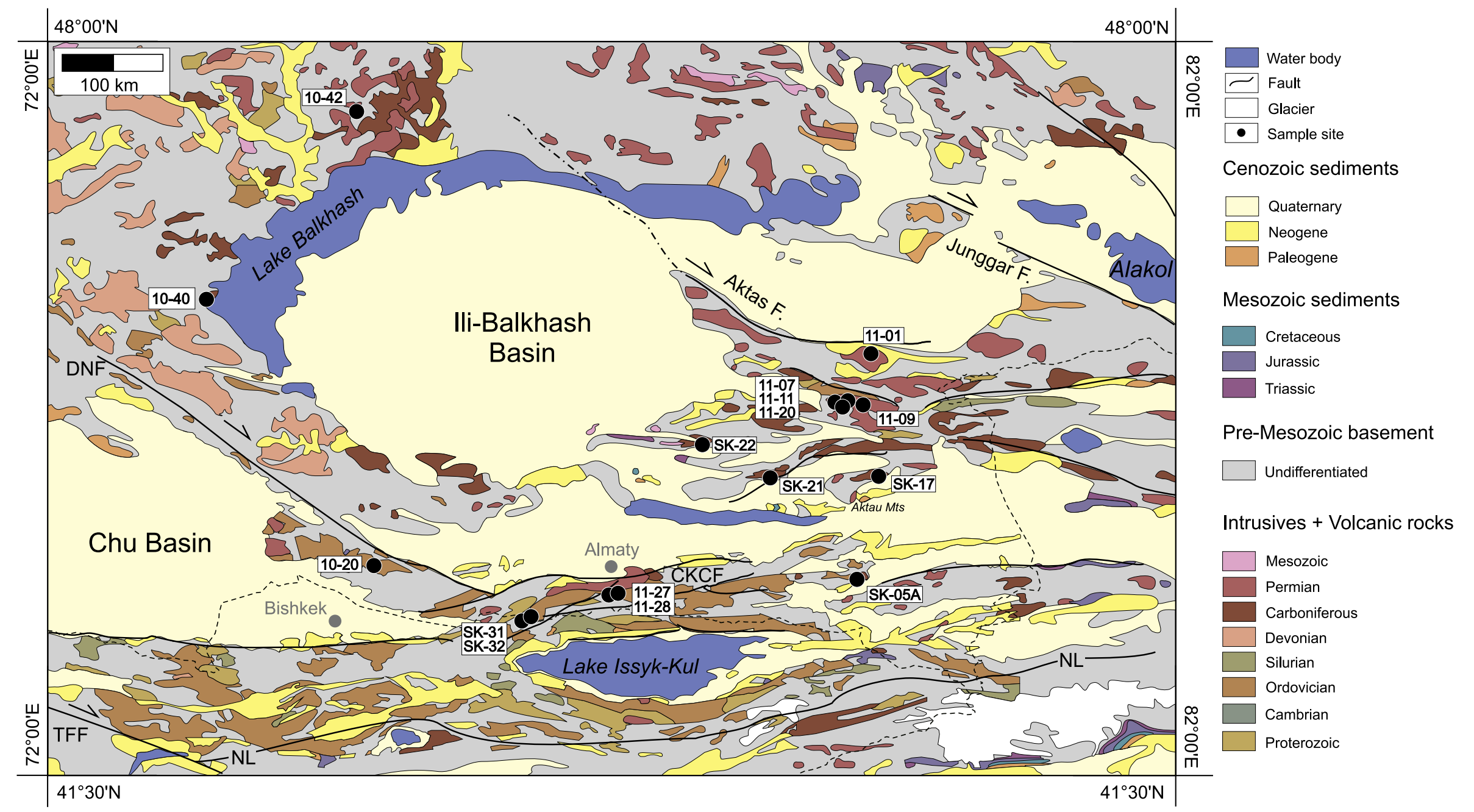

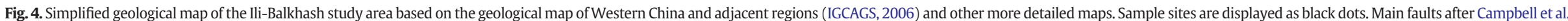
(2013), Choulet et al. (2011) and Delvaux et al. (2001). CKCF $=$ Chon-Kemin-Chilik Fault, DNF = Dzhalair-Naiman Fault, NL = Nikolaev Line, TFF = Talas-Ferghana Fault. F. $=$ Fault, Mts = Mountains. 
collision of the Pamir-Tibetan blocks. In this context, collision of the Qiangtang block took place in the Late Triassic; the Lhasa block in the Late Jurassic-Early Cretaceous; the Karakoram block and the Kohistan-Dras arc in the Late Cretaceous. In addition, the MongolOkhotsk Orogenic Belt (MOOB) was formed by the diachronous oceanic closure between Mongolia-North China and Siberia during the JurassicCretaceous (Metelkin et al., 2010, 2012; Wilhem et al., 2012 and references therein; Zorin, 1999). The MOOB seems to have mainly affected the areas northeast of the Tien Shan (e.g. the Altai-Sayan; Glorie and De Grave, in press).

Following these Mesozoic reactivation episodes, the study area became tectonically more stable and evidence exists that a mature peneplain developed during the Late Cretaceous-early Paleogene (Allen et al., 2001; Bullen et al., 2001, 2003; De Grave et al., 2013; Delvaux et al., 2013; Glorie et al., 2010; Macaulay et al., 2014). Since the early Eocene, major structures in the southern $\mathrm{CAOB}$ were reactivated, which is likely a response to the continuous closure of the Tethys Ocean and associated accretions of island-arcs or continental slivers of 'Greater India' to the southern Eurasian margin (e.g. Glorie and De Grave, in press; Glorie et al., 2011b). From the late Oligocene-Miocene onwards, the southern CAOB was once more subjected to deformation, this time induced by the India-Eurasia collision. This is shown by low temperature thermochronology (e.g. Bullen et al., 2001; De Grave et al., 2013; Glorie et al., 2012a; Hendrix et al., 1994; Macaulay et al., 2014), sedimentology (e.g. Thomas et al., 1999), magnetostratigraphy and structural geology (e.g. Abdrakhmatov et al., 1996; Buslov et al., 2007; Campbell et al., 2013).

\section{Samples and methods}

\subsection{Sample sites}

The basement of SE Kazakhstan, and in particular the Ili-Balkhash study area, can be subdivided into different structural units based on Alexeiev et al. (2011), Kröner et al. (2013) and Windley et al. (2007) (Fig. 3a). The main units can be summarized as: (1) Kyrgyz North Tien Shan (NTS), Chu-Ili (CY) and Aktau-Junggar (AJ) Precambrian microcontinental blocks; (2) Cambrian-Ordovician Dzhalair-Naiman (DN) and Kyrgyz-Terskey (KT) accretionary complexes; (3) dispersed remnants of an Ordovician arc within the Kyrgyz NTS, KT and DN units; (4) Ordovician-Late Devonian North Balkhash (NB) accretionary

Table 2

Operating conditions for ZUPb LA-ICP-MS analysis at the laboratory of Géosciences Rennes, Université Rennes 1, France.

\begin{tabular}{ll}
\hline \multicolumn{2}{l}{ Laser-ablation system ESI NWR193UC } \\
\hline Laser type/wavelength & Excimer $193 \mathrm{~nm}$ \\
Pulse duration & $<5 \mathrm{~ns}$ \\
Energy density on target & $\sim 7 \mathrm{~J} / \mathrm{cm}^{2}$ \\
$\mathrm{ThO}^{+} / \mathrm{Th}^{+}$ & $<0.5 \%$ \\
$\mathrm{He}$ gas flow & $800 \mathrm{ml} / \mathrm{min}$ \\
$\mathrm{N}_{2}$ gas flow & $4 \mathrm{ml} / \mathrm{min}$ \\
Laser repetition rate & $3 \mathrm{~Hz}$ \\
Laser spot size & $25 \mu \mathrm{m}$ \\
& \\
ICP-MS Agilent 7700x & $1350 \mathrm{~W}$ \\
RF power & $5.0-5.5 \mathrm{~mm}$ (optimized daily) \\
Sampling depth & $\sim 0.85 \mathrm{l} / \mathrm{min}$ (optimized daily) \\
Carrier gas flow (Ar) & $16 \mathrm{l} / \mathrm{min}$ \\
Coolant gas flow & Time-resolved analysis \\
Data acquisition protocol & Peak hopping, one point per peak \\
Scanning mode & Pulse counting, dead time correction applied, \\
Detector mode & and analog mode when signal intensity $>\sim 10^{6} \mathrm{cps}$ \\
& $204\left(\mathrm{Hg}+\right.$ Pb), ${ }^{206} \mathrm{~Pb},{ }^{207} \mathrm{~Pb},{ }^{208} \mathrm{~Pb},{ }^{232} \mathrm{Th},{ }^{238} \mathrm{U}$ \\
Isotopes determined & $10-30$ ms \\
Dwell time per isotope & Ni \\
Sampler, skimmer cones & $\mathrm{X}$ type \\
Extraction lenses & \\
\hline
\end{tabular}

complex; (5) Late Devonian-Carboniferous Junggar Balkhash (JB) accretionary complex; (6) Late Devonian-Permian Balkhash-Ili (BY) active continental margin arc and (7) Devonian to Permian epicontinental and non-marine sediments (Chu Basin). In this study, we present 22 new ages (14 apatite fission track and 8 zircon $\mathrm{U}-\mathrm{Pb}$ ages) obtained on 16 basement samples (i.e. granitoids, volcanic tuff and gneiss; Table 1) collected from mountain ranges surrounding the IBB. Sampled mountain ranges are the Kazakh West Junggar, Altyn-Emel, Malaysari, Trans-Ili, Sogeti, Zhetyzol and Chu-Ili Ranges (Table 1, Fig. 2).

In the Kazakh West Junggar Mountains and neighboring ranges, Permian plutons of the Balkhash-Ili (BY) magmatic belt are exposed in the highest mountain ridges (Figs. 2, 3 and 4). These Permian granitoids cross-cut folded Devonian-Carboniferous rocks and are in their turn displaced by strike-slip faults, such as the Aktas Fault (Figs. 2 and 4). Samples 11-01, 11-07 and 11-09 were collected from these Permian granitoids, whereas samples SK-17, SK-21 and SK-22 were taken from surrounding Devonian-Carboniferous magmatic rocks (Fig. 4). Samples 11-11 (diorite) and 11-20 (granite) come from the same location in the Kazakh West Junggar Mountains, but differ in lithology and probably represent a contact zone between Permian and Devonian-Carboniferous intrusions. At the southern border of the IBB, in the Trans-Ili, Sogeti and Zhetyzol Ranges, intrusive bodies are mostly of Late Ordovician-Silurian age, while minor amounts of Carboniferous and Permian intrusive rocks are also common (De Grave et al., 2013; IGCAGS, 2006). From these mountain ranges, granitoid samples 10-20, 11-27, 11-28, SK-05A, SK-31 and SK-32 were collected (Figs. 2 and 4, Table 1). The northern edge of the Zhetyzol Range is defined by the Dzhalair-Naiman strike-slip fault (DNF), which continues westward along the Chu-Ili Range into the Kazakhstan platform (Campbell et al., 2013) (Figs. 2 and 4). More to the south, the Trans-Ili Range is separated from the Kungey Range of the Kyrgyz Tien Shan by the Chon-KeminChilik Fault system (CKCF) (Figs. 2 and 4). To the northwest of the IBB, along the northern continuation of the Chu-Ili Mountains and near Lake Balkhash, samples 10-40 and 10-42 were taken from late Paleozoic (Carboniferous-Permian) granitoid bodies (Figs. 2 and 4, Table 1).

\subsection{Zircon $U-P b(Z U P b)$ dating}

The ZUPb dating method is based on the $(\alpha, \beta)$-decay of ${ }^{238} \mathrm{U}$ and ${ }^{235} \mathrm{U}$ to stable ${ }^{206} \mathrm{~Pb}$ and ${ }^{207} \mathrm{~Pb}$, respectively. Due to its high closure temperature $\left(>800^{\circ} \mathrm{C}\right.$, Cherniak and Watson, 2003), the ZUPb system dates the (re)crystallization of the zircon-bearing basement rock. In the case of unmetamorphosed granitoid rocks, this high-temperature method normally yields the emplacement age of the magmatic body.

For each sample analyzed, around 30-70 zircon grains were handpicked and mounted in epoxy resin, after which their surface was polished. Zircon grains were imaged for their cathodoluminescence (CL) properties, using a JEOL JSM-6400 Scanning Electron Microscope (SEM) at the Department of Geology and Soil Sciences, Ghent University, Belgium. Core-rim relationships were investigated and obvious inclusions and microfractures were avoided during further Laser AblationInductively Coupled Plasma-Mass Spectrometry (LA-ICP-MS) analysis.

The ZUPb analyses were partly carried out at the LA-ICP-MS facility of the Department of Analytical Chemistry at Ghent University (samples 11-01, 11-07, 11-09), following the procedures described in Glorie et al. (2011a, 2015), and partly at the laboratory of Géosciences Rennes at the Université of Rennes 1 in France (samples 11-20, SK-05A, SK-17, SK-21, SK-22), following the procedures described below and listed in Table 2. In the laboratory of Géosciences Rennes, ablation was performed using a ESI NWR193UC laser system, powered by a Coherent ExciStar XS Excimer laser operating at a wavelength of $193 \mathrm{~nm}$. The laser repetition rate was $3 \mathrm{~Hz}$ and the beam diameter $25 \mu \mathrm{m}$. Ablated material was carried to the mass spectrometer using He gas (flow rate $\sim 0.8 \mathrm{l} / \mathrm{min}$ ), and then mixed with $\mathrm{N}_{2}$ (at $\sim 0.04 \mathrm{l} / \mathrm{min}$ ) and $\mathrm{Ar}$ (at $\sim 0.85 \mathrm{l} / \mathrm{min}$ ), before being introduced into the ICP source of an Agilent $7700 \mathrm{x}$ quadrupolebased ICP-MS instrument, equipped with a dual pumping system to 
Table 3

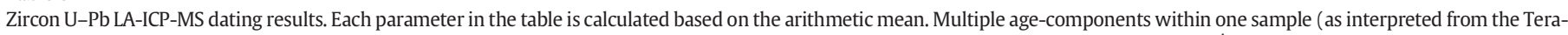

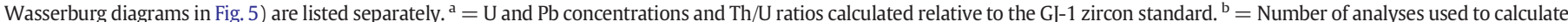

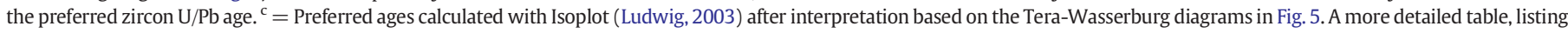
the results for each analyzed spot, can be found in Supplementary Table S1.

\begin{tabular}{|c|c|c|c|c|c|c|c|c|}
\hline Sample name & Sample site & Lithology & $\begin{array}{l}\mathrm{U}^{\mathrm{a}} \\
(\mathrm{ppm})\end{array}$ & $\begin{array}{l}\mathrm{Pb}^{\mathrm{a}} \\
(\mathrm{ppm})\end{array}$ & $\mathrm{Th} / \mathrm{U}^{\mathrm{a}}$ & $\mathrm{N}^{\mathrm{b}}$ & $\begin{array}{l}\text { Preferred age }{ }^{\mathrm{c}} \\
(\mathrm{Ma})\end{array}$ & $\begin{array}{l}\text { Age calculation } \\
\text { (weighted mean) }\end{array}$ \\
\hline $11-01$ & Kazakh W Junggar R. & Granite & 385 & 17 & 0.34 & 18 & $298 \pm 4$ & ${ }^{206} \mathrm{~Pb} /{ }^{238} \mathrm{U}$ age \\
\hline $11-07$ & Kazakh W Junggar R. & Granodiorite & 588 & 26 & 0.73 & 29 & $297 \pm 2$ & ${ }^{206} \mathrm{~Pb} /{ }^{238} \mathrm{U}$ age \\
\hline $11-09$ & Kazakh W Junggar R. & Granodiorite & 4876 & 188 & 0.41 & 17 & $260 \pm 3$ & ${ }^{206} \mathrm{~Pb} /{ }^{238} \mathrm{U}$ age \\
\hline $11-20$ & Kazakh W Junggar R. & Granite & 799 & 45 & 0.68 & 15 & $296 \pm 2$ & ${ }^{206} \mathrm{~Pb} /{ }^{238} \mathrm{U}$ age \\
\hline \multirow[t]{2}{*}{ SK-17 } & Altyn-Emel Range & Tuff & 214 & 8 & 0.60 & 16 & $331 \pm 2$ & ${ }^{206} \mathrm{~Pb} /{ }^{238} \mathrm{U}$ age \\
\hline & & & 226 & 8 & 3.89 & 7 & $311 \pm 4$ & ${ }^{206} \mathrm{~Pb} /{ }^{238} \mathrm{U}$ age \\
\hline SK-21 & Altyn-Emel Range & Granodiorite & 137 & 9 & 0.75 & 34 & $341 \pm 2$ & ${ }^{206} \mathrm{~Pb} /{ }^{238} \mathrm{U}$ age \\
\hline SK-22 & Malaysari Range & Tuff & 167 & 12 & 1.53 & 16 & $320 \pm 2$ & ${ }^{206} \mathrm{~Pb} /{ }^{238} \mathrm{U}$ age \\
\hline \multirow[t]{2}{*}{ SK-05A } & Sogeti Range & Granite & 241 & 15 & 0.73 & 8 & $351 \pm 3$ & ${ }^{206} \mathrm{~Pb} /{ }^{238} \mathrm{U}$ age \\
\hline & & & 227 & 13 & 0.70 & 17 & $332 \pm 2$ & ${ }^{206} \mathrm{~Pb} /{ }^{238} \mathrm{U}$ age \\
\hline
\end{tabular}

enhance sensitivity. Tuning of the instrument and mass calibration were performed using NIST SRM 612 reference glass, by monitoring the ${ }^{238} \mathrm{U}$ signal and minimizing the $\mathrm{ThO}^{+} / \mathrm{Th}^{+}$ratio $(<0.5 \%)$. Analyses consisted of the acquisition of the ${ }^{204}(\mathrm{~Pb}+\mathrm{Hg}),{ }^{206} \mathrm{~Pb},{ }^{207} \mathrm{~Pb},{ }^{208} \mathrm{~Pb},{ }^{232} \mathrm{Th}$ and ${ }^{238} \mathrm{U}$ signal intensities. The ${ }^{235} \mathrm{U}$ abundance was calculated from the signal intensity measured for ${ }^{238} \mathrm{U}$ on the basis of a ${ }^{238} \mathrm{U} /{ }^{235} \mathrm{U}$ ratio of 137.88 (Steiger and Jäger, 1977). Each analysis consisted of a succession of $\sim 20 \mathrm{~s}$ background measurement prior to ablation, followed by $\sim 60 \mathrm{~s}$ of zircon ablation and $\sim 10 \mathrm{~s}$ wash out time. The analyses were performed in time-resolved mode and the raw data were corrected for $\mathrm{Pb} / \mathrm{U}$ and $\mathrm{Pb} / \mathrm{Th}$ laser-induced elemental fractionation and for instrumental mass discrimination by standard bracketing with repeated measurements of the zircon reference material GJ-1 (Jackson et al., 2004). Along with the unknowns, the Plešovice zircon standard (Sláma et al., 2008) was measured to monitor the accuracy. Throughout the entire measurement time, the Plešovice zircon standard provided a concordia age of $336.9 \pm 2 \mathrm{Ma}(\mathrm{N}=17)$, which is in good agreement with the reported ID-TIMS age of $337.1 \pm 0.4 \mathrm{Ma}$ (Sláma et al., 2008). Data reduction was carried out with the GLITTER software package (Jackson et al., 2004) and in-house Excel spreadsheets to deduce the U, Th and Pb concentrations. Ages were calculated with the Isoplot software (Ludwig, 2003) and are presented in Table 3.

\subsection{Apatite fission track (AFT) dating}

Apatite fission track (AFT) dating is a low-temperature thermochronological method based on the spontaneous fission decay of ${ }^{238} \mathrm{U}$, which is present as a trace element in the crystal lattice of apatite. By this process, the apatite lattice accumulates linear radiation damage tracks or fission tracks. At temperatures $(\mathrm{T})$ lower than $\sim 60^{\circ} \mathrm{C}$, fission tracks in apatite are considered stable on geological time scales, whereas at T $>\sim 120-140{ }^{\circ} \mathrm{C}$ (e.g. Ketcham et al., 1999; Wagner and Van den haute, 1992) the crystal lattice regenerates and the fission tracks anneal rapidly. The $\sim 60-120 / 140{ }^{\circ} \mathrm{C}$ window $( \pm 2-4 \mathrm{~km}$ crustal depth) is known as the Apatite Partial Annealing Zone (APAZ) and depends partly on the chemical composition of the apatite crystal (e.g. Barbarand et al., 2003; Carlson et al., 1999; Green et al., 1986; Wagner and Van den haute, 1992). In this temperature window, tracks can accumulate but are progressively shortened (partial annealing), resulting in reduced mean track lengths and broader length-frequency distributions (Gleadow et al., 1986). The AFT age, based on the measurement of the spontaneous fission track density, hence records cooling of the apatite-bearing basement rock through the APAZ. In addition, the AFT length-frequency distribution is a supplementary tool to evaluate the thermal history of the rock. Hence, this allows the reconstruction of basement cooling paths (thermal history modeling; e.g. Gallagher, 2012; Ketcham, 2005; Ketcham et al., 2000), which can be linked to the exhumation history of mountain belts.
All samples were analyzed by the external detector (ED) method with thermal neutron irradiation, following the standard AFT procedure from the geochronology laboratory at Ghent University described by De Grave and Van den haute (2002), De Grave et al. (2009, 2011a) and Glorie et al. (2010). Spontaneous fission tracks in apatite were etched in a $5.5 \mathrm{M} \mathrm{HNO}_{3}$ solution for $20 \mathrm{~s}$ at $21^{\circ} \mathrm{C}$ (Donelick et al., 1999). Irradiation was carried out in the Belgian Reactor 1 (BR1) facility of the Belgian Nuclear Research Centre in Mol. Obtained AFT ages are reported in Table 4 as conventional zeta-ages (Hurford, 1990), calculated using an overall weighted mean zeta of $229.8 \pm 4.9 \mathrm{a} . \mathrm{cm}^{2}$ (personal calibration factor of E. De Pelsmaeker) based on Durango and Fish Canyon Tuff apatite age standards and IRMM 540 dosimeter glasses (De Corte et al., 1998). AFT ages were also calculated as central ages and evaluated by a radial plot to check for potential multiple AFT populations (Galbraith, 1990; Vermeesch, 2009) (Table 4). Where possible, 100 horizontal confined tracks for each sample were measured on prismatic sections parallel to the crystallographic c-axis to construct lengthfrequency distributions, a threshold which was not always attained in this study (Table 4). For some samples, no AFT length data is available due to low spontaneous track densities and/or a low number of suitable grains. To estimate the annealing behavior of the counted grains with measured confined track lengths, measurements of the kinetic parameter $\mathrm{D}_{\text {par }}$ (mean etch pit diameter parallel to the crystallographic c-axis; Carlson et al., 1999; Donelick et al., 2005) were carried out.

Thermal history modeling was performed using the HeFTy software (Ketcham, 2005), the Ketcham et al. (2007) annealing equations and the Monte Carlo search method for inverse modeling. Modelingconstraints were based on geological arguments as expected emplacement ages derived from geological maps and ZUPb and AFT ages obtained in this study. In addition, present-day ambient surface conditions were used as low temperature constraint. In the resulting models, only time-temperature (tT) paths with "good" fits are drawn (Ketcham, 2005).

\section{Results}

\subsection{Zircon $U-P b$ data}

Cathodoluminescence $(\mathrm{CL})$ imaging reveals oscillatory zoning for most of the analyzed zircon crystals, which is indicative for their magmatic origin (Corfu et al., 2003; Hoskin, 2000). Fig. 5 presents the resulting $\mathrm{U}-\mathrm{Pb}$ Tera-Wasserburg diagrams (Isoplot software; Ludwig, 2003), which are characterized by near-concordant CarboniferousPermian zircon age clusters. Most samples in the Tera-Wasserburg diagrams show some dispersion in both ${ }^{207} \mathrm{~Pb} /{ }^{206} \mathrm{~Pb}$ as well as ${ }^{238} \mathrm{U} /{ }^{206} \mathrm{~Pb}$ which is likely related to the presence of a small quantity of common $\mathrm{Pb}$ and minor zero age $\mathrm{Pb}$ loss respectively. As a result, their preferred formation age was calculated from the mean ${ }^{206} \mathrm{~Pb} /{ }^{238} \mathrm{U}$ ratios. For 

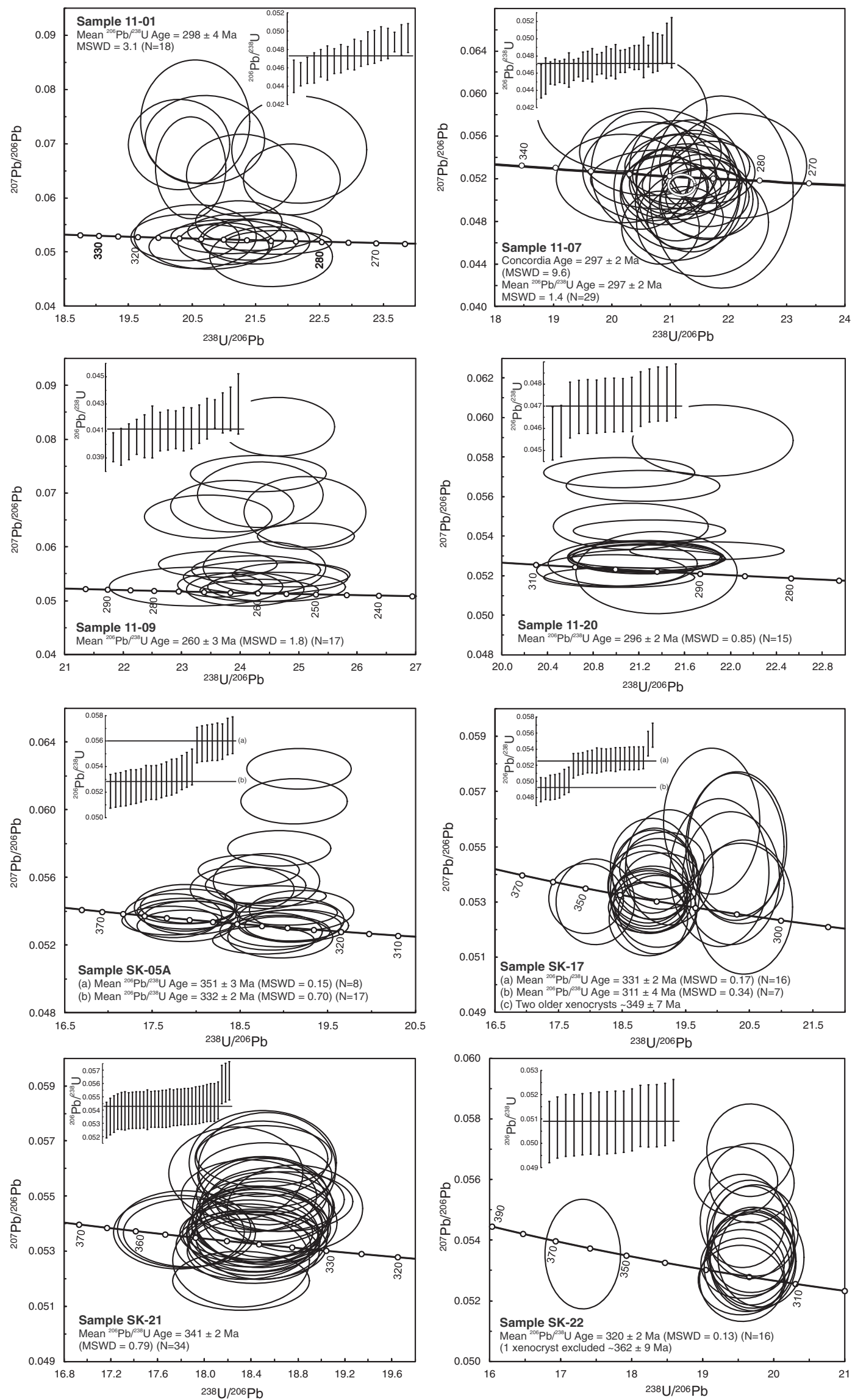

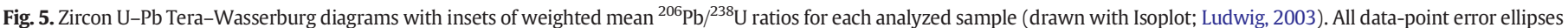
are calculated at $2 \sigma$ level. 


\section{Table 4}

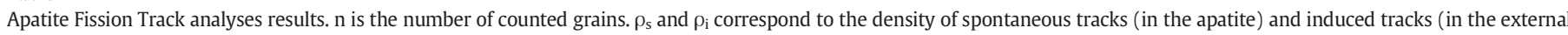

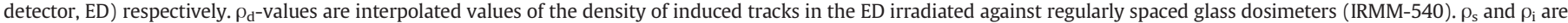

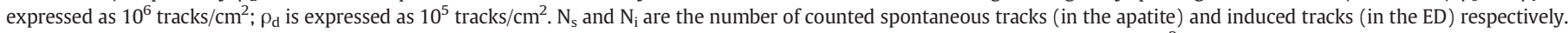

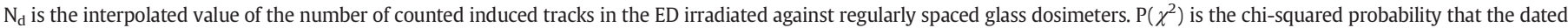

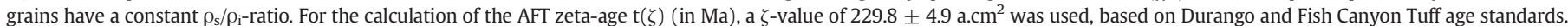

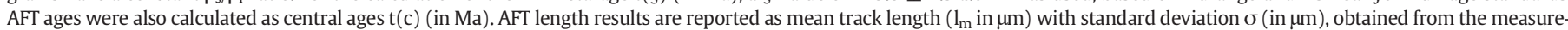

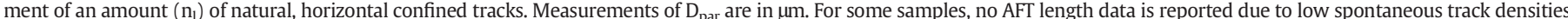

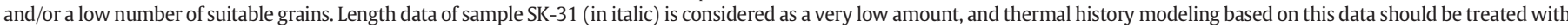
caution.

\begin{tabular}{|c|c|c|c|c|c|c|c|c|c|c|c|c|c|c|}
\hline Sample & $\mathrm{n}$ & $\begin{array}{l}\rho_{s} \\
( \pm 1 \sigma)\end{array}$ & $\mathrm{N}_{\mathrm{s}}$ & $\begin{array}{l}\rho_{\mathrm{i}} \\
( \pm 1 \sigma)\end{array}$ & $\mathrm{N}_{\mathrm{i}}$ & $\begin{array}{l}\rho_{\mathrm{d}} \\
( \pm 1 \sigma)\end{array}$ & $\mathrm{N}_{\mathrm{d}}$ & $\begin{array}{l}\rho_{\mathrm{s}} / \rho_{\mathrm{i}} \\
( \pm 1 \sigma)\end{array}$ & $\begin{array}{l}\mathrm{P} \\
\left(\chi^{2}\right)\end{array}$ & $\begin{array}{l}\mathrm{t}(\zeta) \pm 1 \sigma \\
(\mathrm{Ma})\end{array}$ & $\begin{array}{l}\mathrm{t}(\mathrm{c}) \pm 1 \sigma \\
(\mathrm{Ma})\end{array}$ & $\mathrm{n}_{1}$ & $\begin{array}{l}\mathrm{l}_{\mathrm{m}}( \pm 1 \sigma) \\
(\mu \mathrm{m})\end{array}$ & $\begin{array}{l}\mathrm{D}_{\mathrm{par}}( \pm 1 \sigma) \\
(\mu \mathrm{m})\end{array}$ \\
\hline \multicolumn{15}{|c|}{ Kazakh West Junggar E Altyn-Emel Ranges } \\
\hline $11-01$ & 54 & $3.710(0.105)$ & 1240 & $1.576(0.067)$ & 562 & $3.227(0.071)$ & 2065 & $2.344(0.119)$ & 0.98 & $86.3 \pm 5.1$ & $81 \pm 4$ & 58 & $11.8(1.8)$ & $1.6(0.2)$ \\
\hline $11-07$ & 6 & $0.432(0.078)$ & 31 & $0.277(0.062)$ & 20 & $3.244(0.071)$ & 2076 & $1.544(0.443)$ & 0.95 & $57.3 \pm 16.5$ & $58 \pm 16$ & - & - & - \\
\hline $11-09$ & 28 & $0.775(0.021)$ & 1332 & $0.397(0.015)$ & 685 & $3.298(0.072)$ & 2110 & $2.031(0.095)$ & 0.77 & $76.5 \pm 4.3$ & $73 \pm 3$ & 100 & $14.1(1.2)$ & $3.0(0.3)$ \\
\hline $11-11$ & 56 & $0.637(0.021)$ & 918 & $0.347(0.158)$ & 483 & $3.309(0.072)$ & 2118 & $2.055(0.116)$ & 1.00 & $77.7 \pm 5.0$ & $72 \pm 4$ & 72 & $14.0(1.1)$ & $2.5(0.3)$ \\
\hline $11-20$ & 11 & $0.723(0.042)$ & 295 & $0.278(0.026)$ & 111 & $3.333(0.072)$ & 2133 & $2.579(0.287)$ & 0.95 & $98.0 \pm 11.3$ & $101 \pm 11$ & - & - & - \\
\hline SK-21 & 34 & $1.174(0.036)$ & 1064 & $0.455(0.022)$ & 414 & $3.105(0.070)$ & 1987 & $2.781(0.161)$ & 0.76 & $98.5 \pm 6.5$ & $91 \pm 6$ & 104 & $13.7(1.2)$ & $2.4(0.4)$ \\
\hline \multicolumn{15}{|c|}{ Trans-Ili, Sogeti E' Zhetyzol Ranges } \\
\hline $10-20$ & 17 & $3.692(0.096)$ & 1498 & $1.269(0.057)$ & 500 & $3.187(0.071)$ & 2039 & $3.023(0.157)$ & 0.48 & $109.8 \pm 6.6$ & $108 \pm 6$ & 103 & $13.5(1.1)$ & $2.0(0.3)$ \\
\hline $11-27$ & 58 & $0.150(0.007)$ & 414 & $0.583(0.014)$ & 1709 & $3.345(0.072)$ & 2141 & $0.264(0.014)$ & 0.78 & $10.1 \pm 0.6$ & $9 \pm 1$ & - & - & - \\
\hline $11-28$ & 58 & $0.330(0.011)$ & 926 & $0.772(0.016)$ & 2265 & $3.356(0.072)$ & 2148 & $0.435(0.017)$ & 0.82 & $16.8 \pm 0.8$ & $16 \pm 1$ & 65 & $13.9(1.5)$ & $2.0(0.2)$ \\
\hline SK-05A & 45 & $0.393(0.017)$ & 529 & $0.117(0.009)$ & 154 & $3.087(0.070)$ & 1976 & $3.653(0.335)$ & 0.99 & $128.3 \pm 12.4$ & $121 \pm 11$ & - & - & - \\
\hline SK-31 & 50 & $0.423(0.011)$ & 1410 & $0.189(0.007)$ & 645 & $3.120(0.070)$ & 1997 & $2.388(0.114)$ & 0.88 & $85.1 \pm 4.8$ & $78 \pm 4$ & 27 & $13.2(1.5)$ & $2.1(0.3)$ \\
\hline SK-32 & 41 & $0.504(0.014)$ & 1309 & $0.168(0.008)$ & 415 & $3.127(0.070)$ & 2002 & $3.383(0.191)$ & 1.00 & $120.4 \pm 7.7$ & $112 \pm 6$ & 40 & $13.8(1.2)$ & $1.7(0.2)$ \\
\hline \multicolumn{15}{|c|}{ NW Lake Balkhash } \\
\hline $10-40$ & 19 & $0.354(0.022)$ & 259 & $0.162(0.016)$ & 107 & $3.196(0.071)$ & 2045 & $2.469(0.284)$ & 0.97 & $90.0 \pm 10.7$ & $88 \pm 10$ & - & - & - \\
\hline $10-42$ & 6 & $1.625(0.126)$ & 167 & $0.803(0.092)$ & 77 & $3.216(0.071)$ & 2058 & $2.013(0.277)$ & 0.87 & $74.0 \pm 10.4$ & $80 \pm 11$ & - & - & - \\
\hline
\end{tabular}

each sample, weighted mean ${ }^{206} \mathrm{~Pb} /{ }^{238} \mathrm{U}$ plots are shown in Fig. 5 as well.

Three samples from the Altyn-Emel and Malaysari Ranges, located at the southwestern part of the Kazakh West Junggar Mountains (SK17, SK-21, SK-22) and one from the Sogeti Range (SK-05A) yield Carboniferous zircon crystallization ages (Figs. 5 and 6, Table 3). Sample SK-05A exhibits two apparent age clusters (Fig. 5, Table 3). An older weighted mean ${ }^{206} \mathrm{~Pb} /{ }^{238} \mathrm{U}$ age of $351 \pm 3 \mathrm{Ma}(\mathrm{MSWD}=0.15)$ and a younger weighted mean ${ }^{206} \mathrm{~Pb} /{ }^{238} \mathrm{U}$ age of $332 \pm 2 \mathrm{Ma}$ (MSWD = 0.70). The older (ca. $350 \mathrm{Ma}$ ) age was exclusively obtained from zircon cores, while the younger (ca. $331 \mathrm{Ma}$ ) age comes from zircon rims or grains without any core-rim relationships. We suggest that the age of $332 \pm 2$ Ma corresponds to the zircon crystallization age of sample SK-05A, while the older (ca. $350 \mathrm{Ma}$ ) zircons are inherited in the 330 Ma magma.

The Tera-Wasserburg diagram for sample SK-17 displays three apparent zircon $\mathrm{U}-\mathrm{Pb}$ age populations (Fig. 5). The bulk of the measurements (16 out of 25) yield a near-concordant weighted mean ${ }^{206} \mathrm{~Pb} /{ }^{238} \mathrm{U}$ age of $331 \pm 2 \mathrm{Ma}(\mathrm{MSWD}=0.17)$. In addition, seven analyses yield a younger age of $311 \pm 4 \mathrm{Ma}(\mathrm{MSWD}=0.34)$ and two older zircon grains were dated as $\sim 350 \mathrm{Ma}$. No clear core-rim relationships or variations in $\mathrm{Th} / \mathrm{U}$ ratios were observed for this sample. The excellent correlation of the older ( $\mathrm{ca} .350 \mathrm{Ma}$ ) zircons with the ages obtained for the zircon cores in sample SK-05A (Fig. 5), likely indicate that the ca. $350 \mathrm{Ma}$ age corresponds to the age of zircon xenocrysts and that the ca. $330 \mathrm{Ma}$ age corresponds to the magma crystallization age. The younger $\sim 310 \mathrm{Ma}$ analyses show more dispersion and may reflect partial $\mathrm{Pb}$-loss during a later event in combination with a small quantity of common $\mathrm{Pb}$ in the grains. The Tera-Wasserburg diagram for sample SK-21 (Fig. 5) shows some dispersion in ${ }^{207} \mathrm{~Pb} /{ }^{206} \mathrm{~Pb}$ ratios, however no clear core-rim correlations were observed to identify different zircon age populations. Therefore, an overall weighted mean ${ }^{206} \mathrm{~Pb} /{ }^{238} \mathrm{U}$ age of $341 \pm 2 \mathrm{Ma}(\mathrm{MSWD}=$ 0.79 ) was calculated and interpreted as the best estimate for the crystallization age. For sample SK-22 only one clear age cluster was identified, excluding one older xenocryst of $\sim 363 \mathrm{Ma}$ (Fig. 5). Although minor dispersion in ${ }^{207} \mathrm{~Pb} / 206 \mathrm{~Pb}$ was observed, a statistically acceptable weighted mean ${ }^{206} \mathrm{~Pb} /{ }^{238} \mathrm{U}$ age of $320 \pm 2 \mathrm{Ma}(\mathrm{MSWD}=0.13)$ was obtained which is interpreted as the crystallization age for sample SK-22.
For the central part of the Kazakh West Junggar Range, consistent early Permian zircon crystallization ages ( 296-298 Ma) were obtained for samples 11-01, 11-07 and 11-20 (Figs. 5 and 6; Table 3). The TeraWasserburg diagram for sample 11-01 shows a rather large dispersion in both ${ }^{206} \mathrm{~Pb} /{ }^{238} \mathrm{U}$ and ${ }^{207} \mathrm{~Pb} /{ }^{206} \mathrm{~Pb}$. Given that no clear core-rim relations were observed, a weighted mean ${ }^{206} \mathrm{~Pb} /{ }^{238} \mathrm{U}$ age of $298 \pm 4 \mathrm{Ma}$ $(\mathrm{MSWD}=3.1)$ was obtained as the preferred crystallization age. For sample 11-07 a concordant ZUPb age of $297 \pm 2$ Ma was obtained. However, given the large MSWD of 9.6, a weighted mean ${ }^{206} \mathrm{~Pb} /{ }^{238} \mathrm{U}$ age was calculated which is identical to the concordant age but yields a much smaller MSWD of 1.4. Sample 11-20 exhibits rather large dispersion in ${ }^{207} \mathrm{~Pb} /{ }^{206} \mathrm{~Pb}$ and yields a weighted mean ${ }^{206} \mathrm{~Pb} /{ }^{238} \mathrm{U}$ age of $296 \pm 2 \mathrm{Ma}$ $($ MSWD $=0.85)$. For sample 11-09, which was taken from the same region, a younger (late Permian) ZUPb age was obtained. The TeraWasserburg diagram (Fig. 5) shows rather large dispersion in both ${ }^{206} \mathrm{~Pb} /{ }^{238} \mathrm{U}$ and ${ }^{207} \mathrm{~Pb} /{ }^{206} \mathrm{~Pb}$. Therefore a weighted mean ${ }^{206} \mathrm{~Pb} /{ }^{238} \mathrm{U}$ age of $260 \pm 3 \mathrm{Ma}(\mathrm{MSWD}=1.8$ ) was calculated, interpreted as the crystallization age.

\subsection{Apatite fission-track data}

AFT ages are reported as conventional zeta- and central-ages in Table 4 and demonstrate their similarity within $1 \sigma$ error (Galbraith, 1990; Hurford, 1990). In addition, all samples fulfill the chi-squared test $(>5 \%)$ and hence no indications exist for multiple apatite age populations. Therefore, only the zeta-ages will be reported in the following sections and figures. All analyzed samples from the Kazakh West Junggar, Malaysari and Altyn-Emel Ranges (11-01, 11-09, 11-11, 1120, SK-21) exhibit Late Cretaceous ( 99-77 Ma) AFT ages, except sample 11-07 which has an AFT age of $57 \pm 17$ Ma (Fig. 6, Table 4). For the latter sample, only six grains could be counted, leading to a less precise AFT age (Table 4). Samples 10-40 and 10-42, located NW of the IBB, yield similar Late Cretaceous ( 90-74 Ma) AFT ages (Fig. 6, Table 4). From the Trans-Ili, Sogeti and Zhetyzhol Ranges, four samples (SK-05A, SK-31, SK-32, 10-20) exhibit Cretaceous AFT ages, ranging from ca. 128 to $85 \mathrm{Ma}$; whereas two samples (11-27 and 11-28) have Miocene AFT ages ( 17 and $10 \mathrm{Ma}$ ) (Fig. 6, Table 4). 


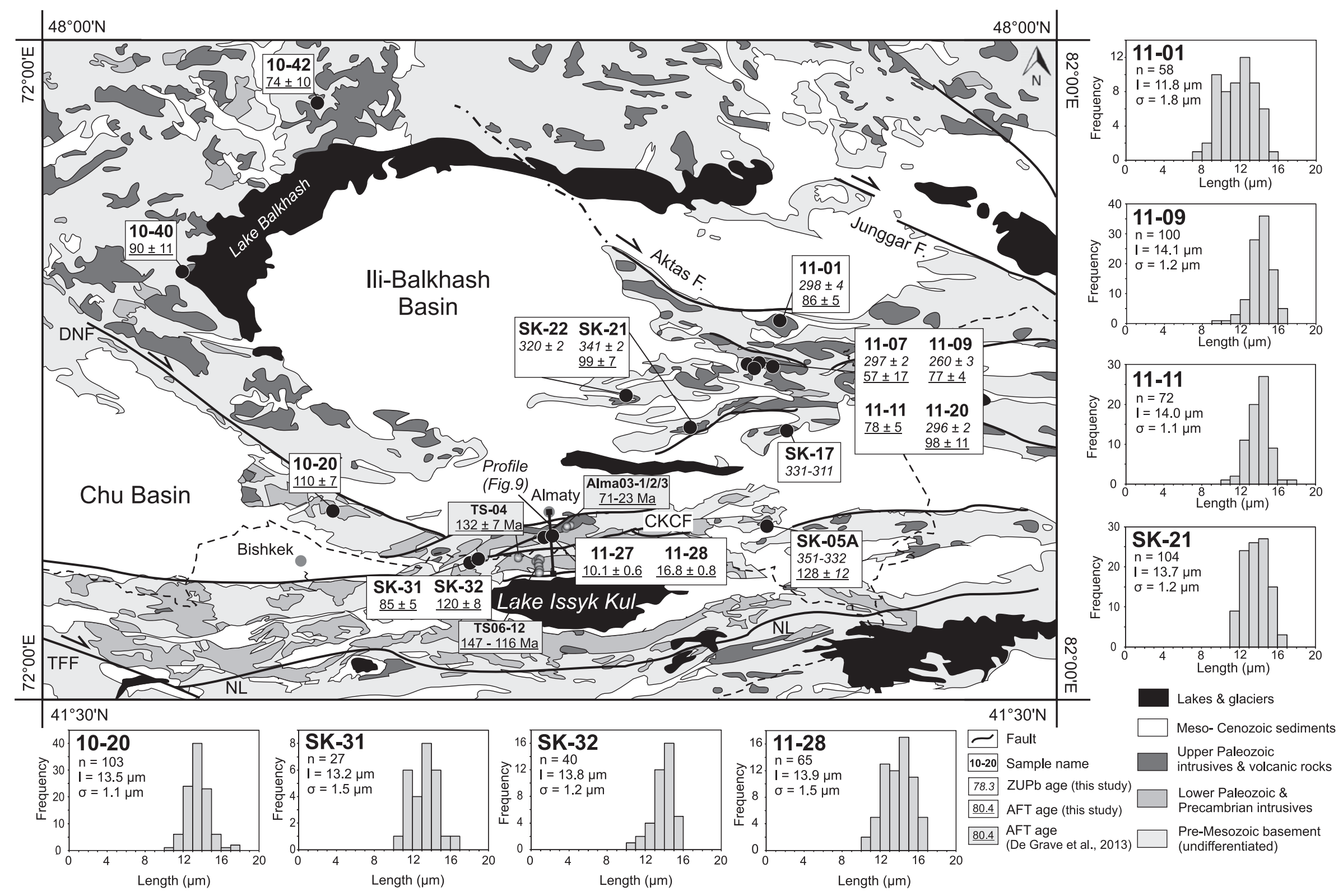

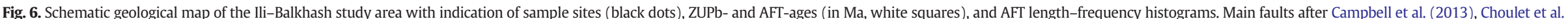
(2011) and Delvaux et al. (2001). CKCF = Chon-Kemin-Chilik Fault zone, DNF = Dzhalair-Naiman Fault, NL = Nikolaev Line, TFF = Talas-Ferghana Fault. 
(a) Kazakh West Junggar \& Altyn-Emel Ranges
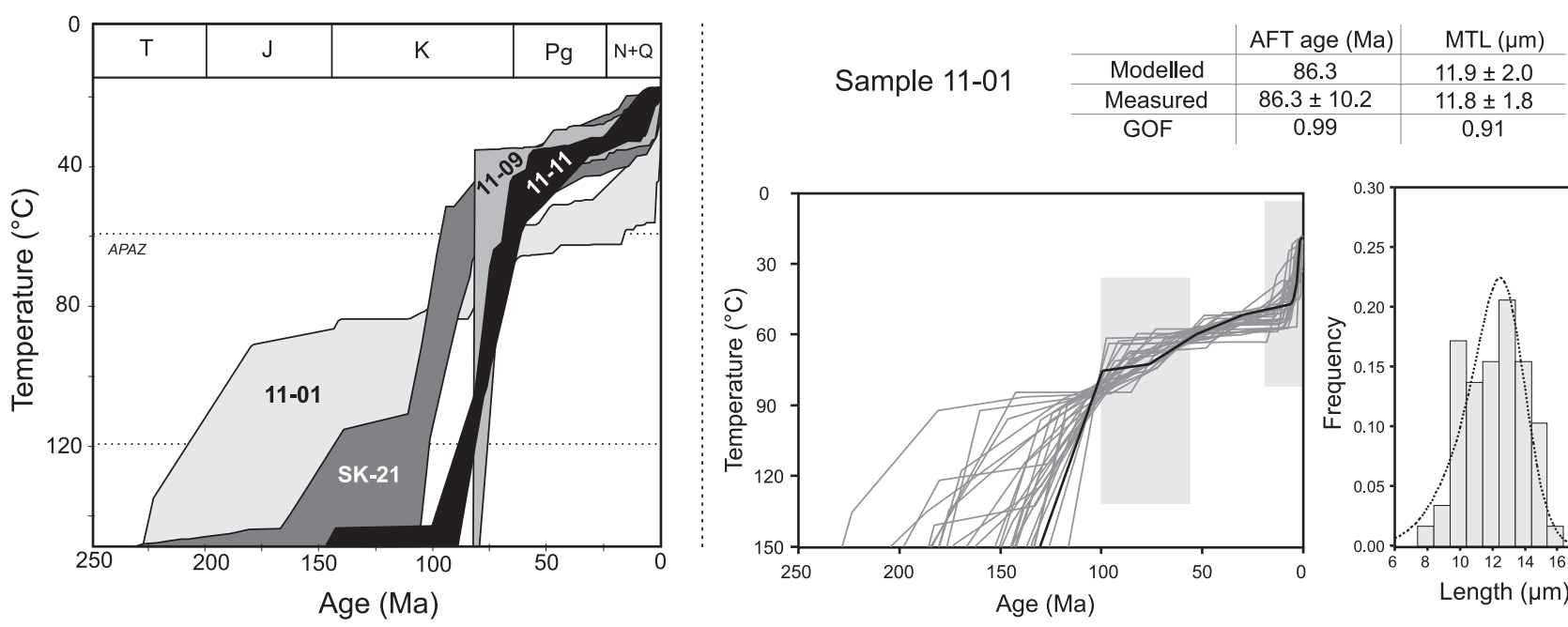

(b) Trans-lli \& Zhetyzol Ranges
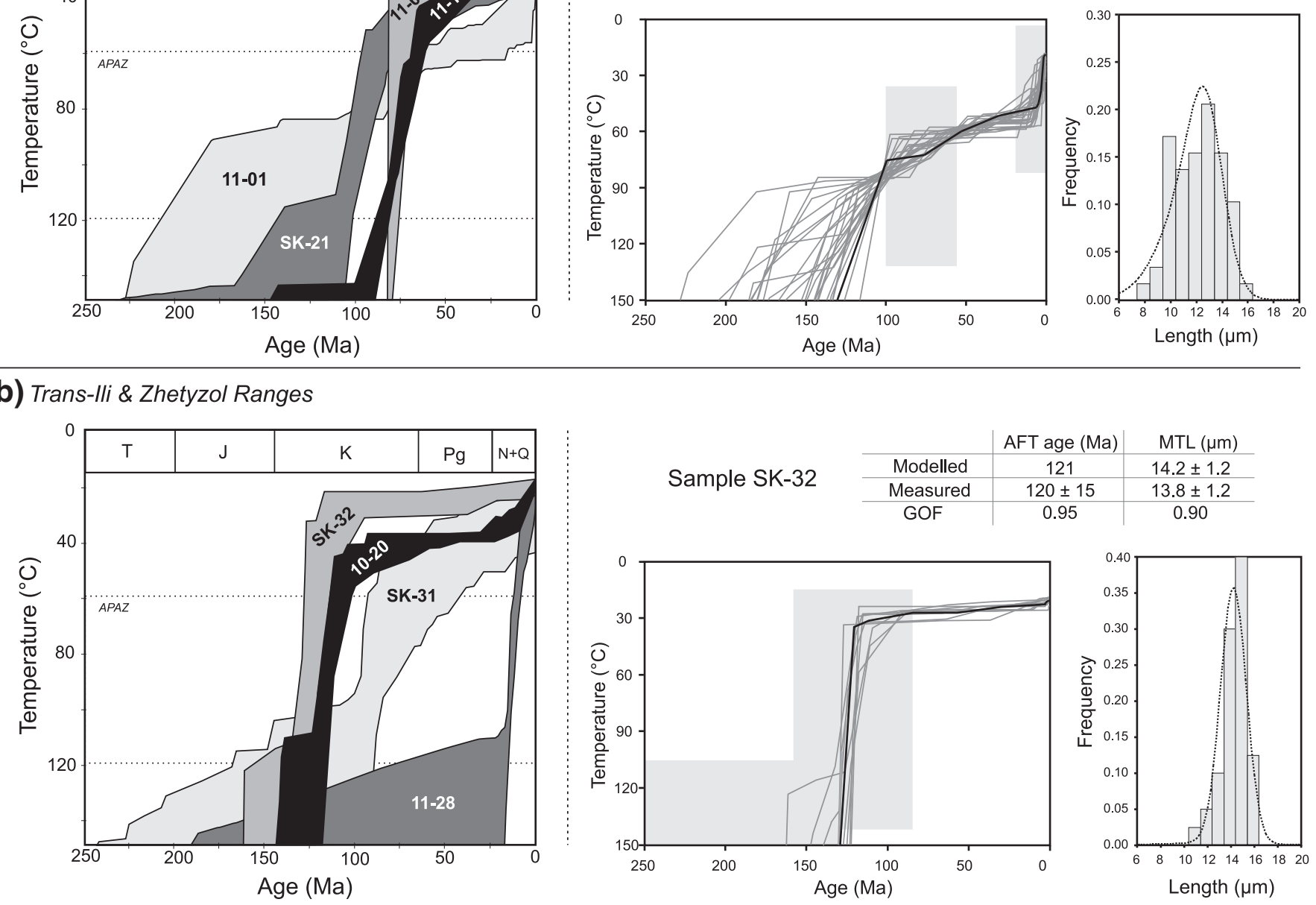

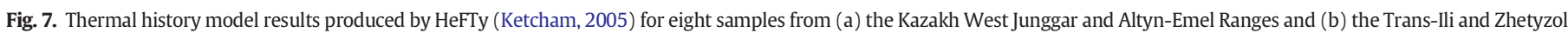

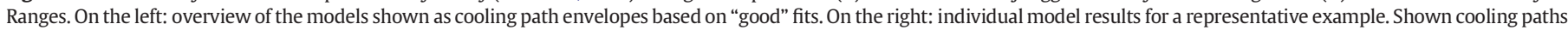

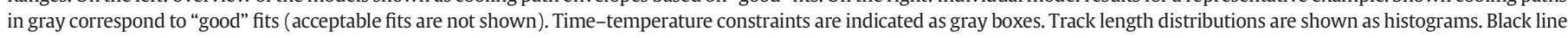

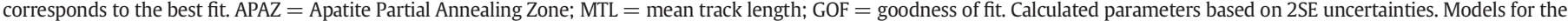
other six samples can be found in the Supplementary Fig. S2.

Most length-frequency distributions exhibit relatively narrow to slightly broader, more or less symmetrical to slightly negatively skewed histograms with mean track lengths $\left(\mathrm{l}_{\mathrm{m}}\right)$ between 13.2 and $14.1 \mu \mathrm{m}$ (standard deviations between 1.1 and $1.5 \mu \mathrm{m}$ ) (Fig. 6, Table 4). Sample 11-01 from the West Junggar Range has a lower $\mathrm{l}_{\mathrm{m}}$ value, i.e. $11.8 \mu \mathrm{m}$, and is also characterized by the broadest length distribution (standard deviation of $1.8 \mu \mathrm{m}$; pointing to slow cooling through the APAZ) and a mean $D_{\text {par }}$ value of $1.6 \mu \mathrm{m}( \pm 0.2)$, which is the lowest value in this study (Fig. 6, Table 4). Apatite grains with relatively low values of $D_{\text {par }}(\leq 1.75 \mu \mathrm{m}$; Carlson et al., 1999; Donelick et al., 2005) are generally considered as fast-annealing, hence in agreement with the observed shorter track lengths. Most of the modeled samples $(\geq 75 \%)$ however have apatite grains with $D_{\text {par }}$ values $>1.75 \mu \mathrm{m}$, which are usually more resistant to annealing (Carlson et al., 1999; Donelick et al., 2005).

In total, eight thermal history models (THMs) were generated using the HeFTy software (Ketcham, 2005) based on samples with sufficient to acceptable numbers of horizontal confined tracks, except for sample SK-31 which has in fact an insufficient number of length data $(\mathrm{n}=27)$. However, modeling is also carried out for sample SK-31 for comparison purposes seeing its similar trend. The THMs are grouped in Fig. 7 by regional setting, resulting in four models for samples from the Kazakh West Junggar-Altyn-Emel Ranges (11-01, 11-09, 11-11 and SK-21) and four models for samples from the Trans-Ili-Zhetyzhol Ranges (10-20, 11-28, SK-31, SK-32). Generally, caution is needed when interpreting the THMs, because the model results are poorly constrained at temperatures outside the PAZ. For the Kazakh West Junggar-Altyn-Emel Ranges (Fig. 7a), the four THMs indicate a well-defined phase of rapid cooling during the Late Cretaceous ( 100-70 Ma). This Cretaceous cooling seems to start slightly earlier ( $150-120 \mathrm{Ma})$ for samples SK-21 and 11-01 based on the THMs. After this relatively rapid cooling event, a stable to very slow cooling phase during the Paleogene is observed in all four models. Finally, around the Paleogene-Neogene boundary, cooling rates seem to increase slightly, bringing the samples to ambient surface conditions.

THMs for samples SK-32 (Trans-Ili Range) and 10-20 (Zhetyzol Range) show a clear Early to middle Cretaceous cooling phase, followed by a stable period from the Late Cretaceous through the early Cenozoic (Fig. 7b). A renewed, late Cenozoic cooling event might be present in the THM of sample $10-20$, starting around 20-15 Ma. The THM for sample 


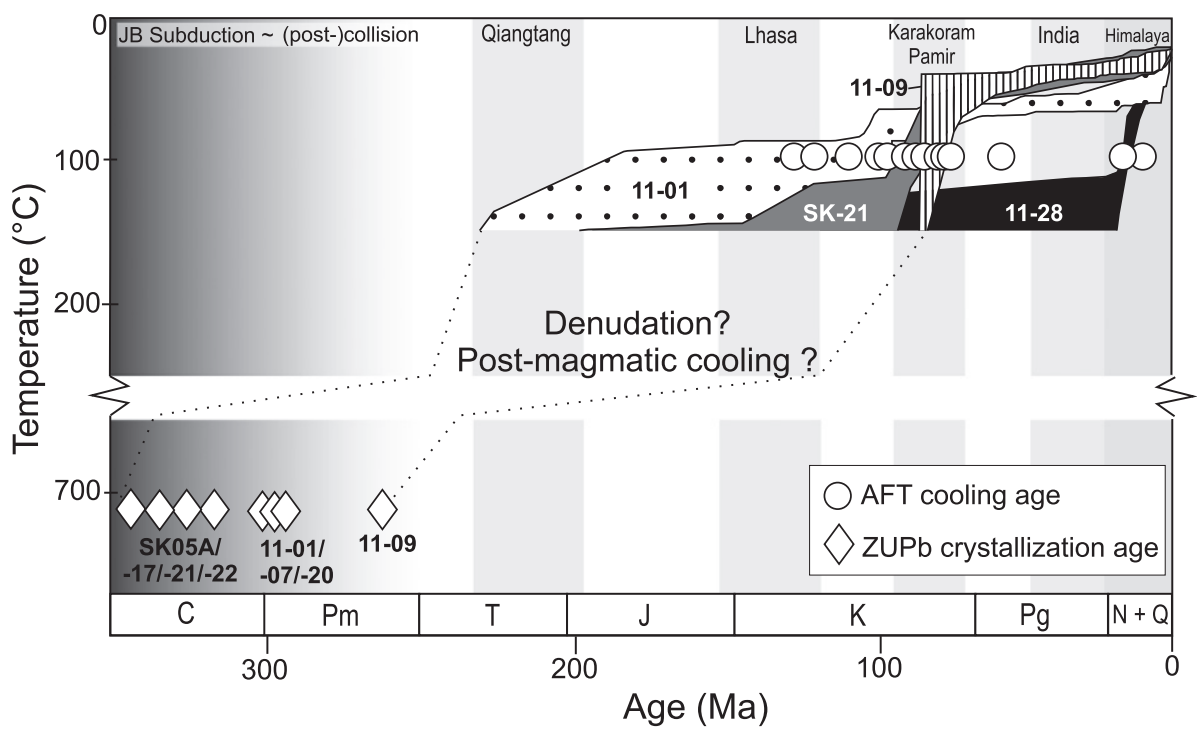

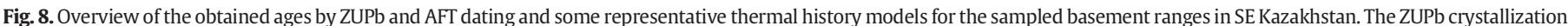

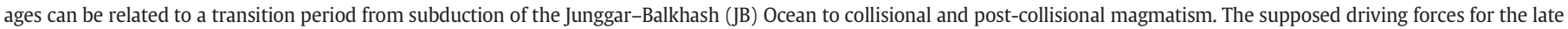

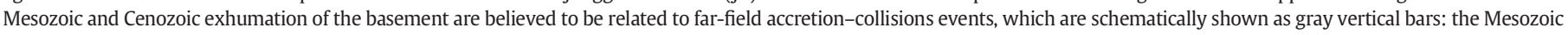
Cimmerian collisions (Qiangtang, Lhasa, Karakoram-Pamir) and Cenozoic India-Eurasia collision.

SK-31 (Trans-Ili Range) show a main cooling phase in the Mesozoic as well, but the cooling paths are less constrained and span the whole Jurassic-Cretaceous epochs. A late Cenozoic renewed cooling is not clearly visible in the THM of the latter sample. In contrast, in the THM of sample 11-28 (AFT age of $17 \mathrm{Ma}$ ) from the Trans-Ili Range as well, a pronounced late Cenozoic cooling phase is obviously present since \pm 20 Ma which brought the sample to ambient surface conditions, effectively exhuming a deeper paleo-crustal level (Fig. 7b).

\section{Discussion}

\subsection{Zircon $U-P b$ data}

The four analyzed magmatic samples from the Altyn-Emel, Malaysari and Sogeti Ranges (SK-05A, SK-17, SK-21, SK-22) exhibit Carboniferous zircon crystallization ages between 341-311 Ma (Figs. 5, 6 and 8). Slightly older zircon grains and zircon cores of $\sim 350 \mathrm{Ma}$ are interpreted as xenocrysts in the $\sim 341-311 \mathrm{Ma}$ magma. The other four granitoid samples $(11-01,11-07,11-09,11-20)$ from the central Kazakh West Junggar Range reveal Permian near-concordant ZUPb ages, of which three of them have consistent early Permian ages ( 298$296 \mathrm{Ma}$ ) and one yields a late Permian age of $260 \pm 3$ Ma (Figs. 5, 6 and 8).

Previously obtained ZUPb ages for the Ili-Balkhash basement in SE Kazakhstan are rather limited, but Chen et al. (2012) reported three phases of pluton intrusions $(335 \pm 2 \mathrm{Ma}, 308 \pm 10 \mathrm{Ma}, 297 \pm 3$ $\mathrm{Ma})$ based on zircon SHRIMP U-Pb geochronology of skarn-related granitoids in the Sayak ore field of the Ili-Balkhash area. According to Shen et al. (2013a) two periods of ore formation in the Kazakh North Balkhash and Chinese West Junggar occurred during the late Paleozoic. A Carboniferous (328-312 Ma) porphyry Cu metallogenic event is related to calc-alkaline arc magmatism whilst early Permian (306-289 Ma) greisen W-Mo metallogenic deposits are associated with alkaline magmatism in a collisional to post-collisional context (Shen et al., 2013a). Also Chen et al. $(2010,2014)$ confirmed that late Paleozoic felsic magmatism occurred mainly during the late Carboniferous to earliest early Permian in that region. Generally, Carboniferous arc magmatism can be related to the subduction of the Junggar-Balkhash Ocean, which resulted in the formation of the Balkhash-Ili (BY) magmatic belt in SE Kazakhstan (Heinhorst et al., 2000; Korobkin and Buslov, 2011; Levashova et al., 2012; Xiao et al., 2010) (Fig. 3). This subduction zone was responsible for the formation of an extensive Late Devonianearly Permian magmatic belt, of which remnants can be found in East Kazakhstan, West Junggar and the Chinese northern Tien Shan (Charvet et al., 2007; Choulet et al., 2011, 2012, 2013; Filippova et al., 2001; Kröner et al., 2008; Tang et al., 2010; Wilhem et al., 2012; Windley et al., 2007; Xiao et al., 2010, 2013; Zhao and He, 2013). In the Chinese West Junggar, most late Paleozoic plutons range in age from 360 to $280 \mathrm{Ma}$ (with a peak between 340 and $300 \mathrm{Ma}$ ) based on zircon U-Pb ages from Gao et al. (2014), Guo et al. (2010), Han et al. (2006), Li et al. (2014), Tang et al. (2010), Wei et al. (2011) and Zhu et al. (2007). In that region, calc-alkaline arc magmatism (characterized mainly by I-type granites) dominated around $\sim 380-305 \mathrm{Ma}$ (e.g. Choulet et al., 2011, 2012, 2013; G. Yang et al., 2014; Geng et al., 2011; Shen et al., 2013b; Tang et al., 2010; Yin et al., 2010, 2013; Zhou et al., 2008). The Carboniferous ( 350-311 Ma) crystallization ages obtained in this study for the Kazakh West Junggar and neighboring mountain ranges, are likely related to this arc magmatism. The combined effect of oceanic closure and oroclinal bending resulted in the continuous reorientation of the magmatic belt and buckling of the active margin (Abrajevitch et al., 2008; Choulet et al., 2012, 2013; Levashova et al., 2012; Wilhem et al., 2012). Contemporaneous local extension at the periphery of the Kazakhstan Orocline resulted in the creation of small transtensional sedimentary basins, and is likely a flexural response of the oroclinal bending process (Abrajevitch et al., 2008). An example is the Chu-(Sarysu) Basin in SE Kazakhstan which accommodated more than $6 \mathrm{~km}$ of Devonian to Permian continental and shallow-marine sedimentary deposits (Abrajevitch et al., 2008 and references therein) (Fig. 3a).

By the early Permian, the Junggar-Balkhash Ocean was almost entirely closed (Choulet et al., 2012; Feng et al., 1989; Wilhem et al., 2012; Windley et al., 2007). During the Permian, the geodynamic setting changed to a (post-) collisional environment and the area was affected by large-scale deformation and strike-slip faulting (e.g. Abrajevitch et al., 2008; Buslov et al., 2003b; Choulet et al., 2011, 2012, 2013; Korobkin and Buslov, 2011; Levashova et al., 2012; Van der Voo et al., 2006; Wang et al., 2007). The Talas-Ferghana Fault (TFF; Rolland et al., 2013), the Irtysh Shear Zone (ISZ) (Buslov et al., 2004; Glorie et al., 2012b) and the Chingiz-Alakol-North Tien Shan shear zone (CANTF; Choulet et al., 2011) are important examples of such strike-slip systems near our study area (Figs. 1 and 2). Deformation along the CANTF shear zone took place around 290-240 Ma, leading 
to a displacement of $490 \mathrm{~km} \pm 250 \mathrm{~km}$ (Choulet et al., 2011). In the Chinese North Tien Shan, a transition from calc-alkaline arc magmatism to alkaline intraplate anorogenic (or post-collisional) magmatism occurred during the early-middle Permian (B. Wang et al., 2009). In the Chinese West Junggar, transition from a Carboniferous subductionaccretion setting to a Permian post-accretion setting transpired around 305-300 Ma (Choulet et al., 2012, 2013; Gao et al., 2014; Geng et al., 2009, 2011; Tang et al., 2010; Yin et al., 2013; Zhou et al., 2008). Between 300-250 Ma, alkaline magmatism and A-type granites dominated with minor calc-alkaline and I-type granites in an overall post-collisional setting with major strike-slip deformation and associated extensional-transtensional tectonics (Chen and Jahn, 2004; Choulet et al., 2011, 2012, 2013; Tang et al., 2010; Zhang et al., 2008; Zhou et al., 2008). Alternatively, several researchers invoke the possibility of coeval plume magmatism in the Permian (e.g. Dobretsov, 2011; Korobkin and Buslov, 2011). Novikov (2013) reports two Permian orogenic episodes for the Chinese West Junggar, based on evidences from the sedimentary record. A first episode took place around 290$275 \mathrm{Ma}$ and a second phase around 265-255 Ma. These episodes are in agreement with the overall timing of collisional to post-collisional magmatism and can potentially be correlated to the early ( 298 $296 \mathrm{Ma}$ ) and late ( 260 Ma) Permian ZUPb ages for the Kazakh West Junggar basement from this study. Also Kröner et al. (2008) and Shen et al. (2013a) reported the existence of Permian anorogenic, alkaline magmatism in East Kazakhstan.

In the broader Tien Shan and Altai regions, late Paleozoic granitoid intrusives are widespread as well. In the Kyrgyz Tien Shan and Chinese Central-South Tien Shan, widespread late Carboniferous-Permian collisional and post-collisional intrusions are reported by e.g. Biske et al. (2013), De Grave et al. (2013), Dumitru et al. (2001), Glorie et al. (2010, 2011a), Han et al. (2010), Konopelko et al. (2007), Liu et al. (2014), Ren et al. (2011) and Seltmann et al. (2011). In the southern Siberian Altai region, (post-) collisional intrusives are dated as late Carboniferous-early Permian (Glorie et al., 2011a). In the Chinese Altai, Tong et al. (2014) argued that post-collisional Permian intrusives were mostly emplaced during the 287-267 Ma interval. Generally, these intrusions are related to the closure of the Turkestan and ObZaisan Oceans at the southeastern and northwestern margin of the Kazakhstan paleocontinent respectively (Fig. 3b-c), leading to the late Permian final amalgamation of the ancestral CAOB (Filippova et al., 2001; Wilhem et al., 2012; Windley et al., 2007).

\subsection{AFT data}

The predominantly Cretaceous AFT cooling ages (Figs. 6 and 8) and THMs (Fig. 7) for the Ili-Balkhash basement samples in this study (excluding samples 11-27 and 11-28 from the Trans-Ili Range) can be explained in terms of episodic exhumation and associated basement cooling. Our results will be placed in a broader thermo-tectonic framework based on available data from studies of e.g. Bullen et al. (2001), De Grave et al. (2011a, 2013), Glorie et al. (2010), Macaulay et al. (2014) for the northern Kyrgyz Tien Shan; Dumitru et al. (2001), Jolivet et al. (2010), Hendrix et al. (1992, 1994), Q. Wang et al. (2009) for the Chinese Central and Northern Tien Shan; De Grave et al. (2007, 2008, 2011b), De Grave and Van den haute (2002); Glorie et al. (2012a), Yuan et al. (2006) for the southern Altai mountains. These studies already demonstrate the existence of several reactivation periods after the final amalgamation of the ancestral CAOB in the Permian. Based on the relative consistent two-stage cooling history of our AFT dated samples (Figs. 7 and 8), the thermal history of the Ili-Balkhash basement can be generally summarized as: distinctive cooling during the late Mesozoic, followed by a slow cooling period from the latest Mesozoic through the Paleogene. A third stage of late Oligocene-early Miocene cooling might be present in some of the THMs, but is only outspoken in sample 11-28. Each of these stages will be discussed in the subsequent sections.

\subsubsection{Late Mesozoic reactivation}

In the Tien Shan, the oldest reported AFT ages are Triassic-Early Jurassic, but Late Jurassic and Cretaceous ages compile the bulk of the available AFT data set (De Grave et al., 2013 and references therein; Glorie and De Grave, in press). For the northern Kazakh Tien Shan, De Grave et al. (2013) reported Late Cretaceous and Neogene AFT ages for the Trans-Ili Range, and Late Jurassic-Early Cretaceous ages for the Zhetyzol Range. In the northern Kyrgyz Tien Shan, Early Cretaceous AFT ages are characteristic for the central Kungey Range, while many Early to Late Cretaceous AFT ages were obtained for the Terskey Range (De Grave et al., 2013; Macaulay et al., 2014; Sobel et al., 2006). Furthermore, in and around the Chinese part of the Ili Basin, Cretaceous AFT ages are reported by Jolivet et al. (2010) and north of Lake Balkhash (in the Sayak ore field) Late Cretaceous AFT ages are reported by Chen et al. (2012). Hence, the AFT age results from this study are consistent with the aforementioned previous studies, with Early Cretaceous and Miocene ages for the Trans-Ili and Sogeti Ranges, Early Cretaceous ages for the Zhetyzol Range and Late Cretaceous to early Paleocene ages for the Kazakh West Junggar Range and the region NW of Lake Balkhash (Fig. 6). Despite the consistent Cretaceous ages, it remains difficult to make well-defined regional clusters of related AFT age data. In general, the somewhat younger Late Cretaceous to early Paleocene ages ( 99 to $57 \mathrm{Ma}$ ) found in and around the Kazakh West Junggar Mountains and NW of Lake Balkhash indicate that the basement there exhumed more rapidly (i.e. deeper paleo-levels are now exposed) compared to the Sogeti and Zhetyzhol Ranges more to the south, which are characterized by older Early Cretaceous AFT ages ( 128 to $110 \mathrm{Ma}$ ).

The predominantly Cretaceous AFT ages and THMs for the IliBalkhash basement generally point to a late Mesozoic cooling episode associated with basement denudation. For the Kazakh-Kyrgyz northern Tien Shan, earlier published data already demonstrated the existence of Mesozoic cooling/denudation periods. A Middle Jurassic to Early Cretaceous cooling phase is identified in the Zhetyzol and Kungey Ranges, while for the Trans-Ili and Terskey Ranges a Late Cretaceous cooling phase is recognized (De Grave et al., 2013). In contrast, Macaulay et al. (2014) only identified an Early Jurassic cooling event (200-150 Ma) in the mountain ranges south of Issyk-Kul (including the Terskey Range). In the Chinese Central Tien Shan, Hendrix et al. (1992) reported three main Mesozoic cooling episodes, namely in the latest Triassic, latest Jurassic and Late Cretaceous. Dumitru et al. (2001) and Q. Wang et al. (2009) also identified a late Mesozoic cooling episode for the Chinese Central Tien Shan, while Jolivet et al. (2010) reported a broad early Permian to Middle Jurassic cooling period followed by a shorter cooling pulse around the Late Cretaceous-Paleogene (65-60 Ma). This Late Cretaceous-Paleogene pulse is mostly characterized by localized uplift along major strike-slip faults south of the Chinese part of the Ili Basin (Jolivet et al., 2010). Also Li et al. $(2008,2014)$ reported a Cretaceous cooling event based on AFT and apatite (U-Th)/He ages of West Junggar basement rocks. Generally, these Mesozoic cooling phases in the Tien Shan are usually interpreted as far-field effects of Mesozoic collisions at the southern Eurasian margin (e.g. De Grave et al., 2007, 2013; Dumitru et al., 2001; Hendrix et al., 1992; Li et al., 2014; Q. Wang et al., 2009). Progressive closure of the Paleo-Tethys Ocean and subsequent collisions of the Cimmerian blocks are believed to be responsible for the various cooling and denudation episodes in southern Central Asia during the Mesozoic (collision of the Qiangtang block in the Late Triassic, the Lhasa block in the Late Jurassic-Early Cretaceous, the Karakoram block and the Kohistan-Dras arc in the Late Cretaceous; e.g. Golonka, 2004; Kapp et al., 2003; Metcalfe, 2013; Roger et al., 2010). In addition, far-field effects of the MOOB to the NE of the study area during the Jurassic-Cretaceous cannot be excluded, although its extent and influence is at present highly contested (e.g. Jolivet et al., 2010, 2013a, 2013b; Metelkin et al., 2010; Wilhem et al., 2012 and references therein). In the southern Altai Mountains, several AFT studies point to a Late Jurassic-Cretaceous basement cooling event, which is generally linked to both the Mongol-Okhotsk and the Cimmerian 


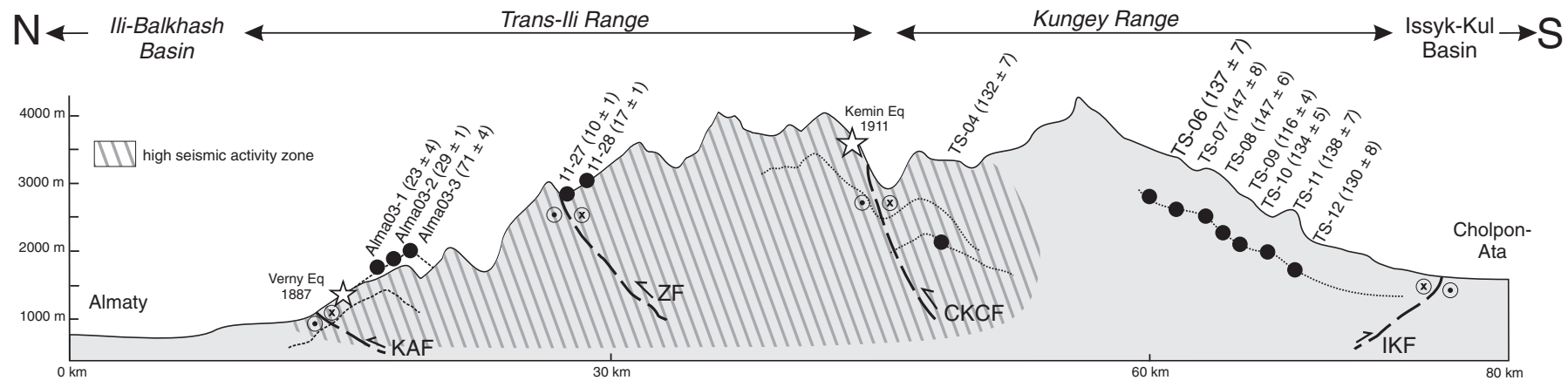

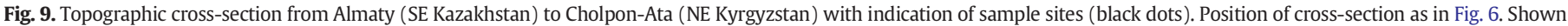

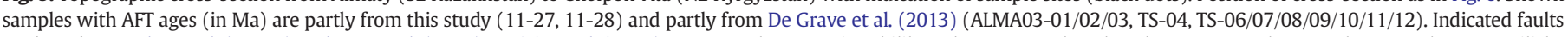

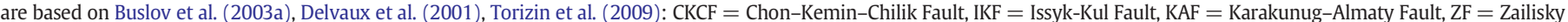

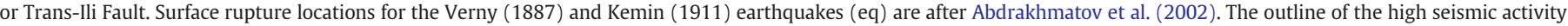
zone is based on Torizin et al. (2009).

Orogeny during the Mesozoic (Cogné et al., 2005; De Grave et al., 2007, 2008; Glorie et al., 2012a, 2012b; Halim et al., 1998; Yuan et al., 2006). However, most authors favor the Mongol-Okhotsk Orogeny and subsequent collapse as the main driving force for the Late Jurassic-Cretaceous cooling and denudation in the Altai, given the more proximal location of the Altai to the Mongol-Okhotsk collision zone. The widespread Cretaceous AFT ages and late Mesozoic cooling episode obtained for the Ili-Balkhash basement ranges are hence compatible with previous thermo-tectonic studies in the adjoining area, and are interpreted in the same context, mainly as far-field effects of the Cimmerian collisions at the southern Eurasian margin and possibly also of the MongolOkhotsk Orogeny in SE Siberia during the Jurassic-Cretaceous (Choulet et al., 2013; De Grave et al., 2007, 2013; Dumitru et al., 2001; Hendrix et al., 1992; Jolivet et al., 2013b) (Fig. 8). The variation in timing of the late Mesozoic cooling (and AFT ages) can be attributed to distinct tectonic movements and differences in exhumation rate and intensity between particular basement blocks.

In the Issyk-Kul Basin, the Mesozoic sedimentary record contains a few hundred meters of Upper Triassic-Jurassic sediments and minor Cretaceous deposits (Cobbold et al., 1994), while in the southern Junggar Basin, the Mesozoic sedimentary pile is thicker and ends with Cretaceous coarse clastic sediments (Allen et al., 1995; Hendrix et al., 1992; Jolivet et al., 2010; Wang et al., 2013; Yang et al., 2015). Unfortunately, in the IBB, the Mesozoic sedimentary record is relatively poorly known, making direct correlation between the Mesozoic exhumation history and the resulting sediment supply not straightforward. However, the clear presence of Jurassic-Cretaceous sediments in the nearby area is consistent with the interpretation of late Mesozoic basement denudation. A lot of studies demonstrate that Mesozoic deformation in the Tien Shan and Altai was periodical (e.g. Dumitru et al., 2001; Glorie et al., 2011b, 2012b; Hendrix et al., 1992; Jolivet et al., 2010; Yang et al., 2015). For example, Choulet et al. (2013) correlated Mesozoic episodes of strike-slip faulting and coarse-grained detrital sedimentation in the South Junggar Basin with rotational movements between Kazakhstan, Junggar, Tarim and Siberia, which can be seen as effects of the Cimmerian collisions at the southern Eurasian margin. Therefore, the Mesozoic Tien Shan and Altai were probably characterized by localized, differential uplifted ranges and intervening basins. Because of the non-uniform and complex nature of the reactivation, direct correlation between the distant tectonic forces, the timing and distribution of the intracontinental deformation revealed by e.g. AFT dating and the sediment record is not always clear. Discrepancies between the sedimentological record and low-temperature thermochronological data in the Mesozoic are described by Jolivet et al. (2010) for the Chinese IIi Basin, and by Jolivet et al. (2013b) and Vincent and Allen (2001) for the Junggar Basin. Also, Jolivet et al. (in press) demonstrate that the link between tectonic uplift and the sediment record is often not straightforward, and can be considerably modified by climate variations as in the case of the Upper Jurassic-Lower Cretaceous alluvial fan deposits of the Kalaza Formation for example.

\subsubsection{Late Cretaceous-Paleogene tectonic stability}

A slow cooling period from the latest Mesozoic through the Paleogene is clearly present in most THMs (Fig. 7), but some caution is needed to interpret this slow cooling phase because it often takes place at temperatures just outside the PAZ where the sensitivity of the model decreases. However, such a slow cooling period is also recognized in the thermochronological data from the northern Kyrgyz Tien Shan (Bullen et al., 2001, 2003; De Grave et al., 2013; Glorie et al., 2010; Macaulay et al., 2013, 2014) and southern Altai (De Grave and Van den haute, 2002; De Grave et al., 2008; Yuan et al., 2006).

Evidence for this tectonic stable period can also be found in the sedimentary record. In the IBB, the most complete sedimentary section is located south of the Aktau Mountains, situated southwest of the Kazakh West Junggar Range (Figs. 2 and 4). In this region, Cenozoic deposits rest unconformable on Upper Cretaceous sedimentary rocks (Lucas et al., 2000 and references therein). After the deposition of scattered Cretaceous sediments in the IBB and adjoining basins, a regionally extensive peneplain developed. Remnants of these flat erosional surfaces can be found in the Tien Shan and Altai (Allen et al., 2001; De Grave and Van den haute, 2002; Sobel et al., 2006 and references therein). In the IBB, sedimentation resumed during the late Eocene-Oligocene, and became widespread since the early Miocene (Kober et al., 2013; Lucas et al., 1997, 2000). During the late Eocene-early Miocene the deposits were mainly fluvio-lacustrine in origin and reflect distal, low-energy sedimentary environments (Kober et al., 2013; Lucas et al., 1997, 2000). Comparable to the IBB, the adjacent Chu Basin contains $\pm 6 \mathrm{~km}$ of Cenozoic sediments, resting on Cretaceous deposits (Bullen et al., 2001 and references therein). The relative thin Cretaceous-Paleogene strata probably represent low-energy environment sediments, whereas a transition to more fluvial-alluvial sedimentary settings progressed during the Miocene (Bullen et al., 2001). In the Junggar Basin, also limited erosion and associated sedimentation took place during the Paleogene (Wang et al., 2001). Hence, the near lack of sedimentary deposits during the Paleogene in the IBB and adjoining basins is in agreement with the slow basement cooling episode derived from our AFT data.

\subsubsection{Late Cenozoic reactivation}

A late Cenozoic cooling phase might be present in some of the THMs, but is only clearly outspoken in the model of sample 11-28 (Fig. 7). Very precise timing of this cooling phase is difficult because most samples were almost at near-surface temperatures at that time, where the sensitivity of the AFT method is decreasing. Therefore, this event is less outspoken as compared to the late Mesozoic cooling. For some 
samples (e.g. SK-32, Fig. 7) late Cenozoic cooling is lacking because these samples were already brought to ambient surface conditions by the late Mesozoic-early Cenozoic. However, the late Cenozoic cooling event is obviously most pronounced in samples 11-27 and 11-28 from the Trans-Ili Range, which reveal Miocene AFT ages (respectively 10.1 $( \pm 0.6)$ and $16.8( \pm 0.8) \mathrm{Ma})$ (Figs. 6 and 8, Table 4). The THM of sample 11-28 shows a distinct cooling-exhumation phase from below the APAZ to ambient surface conditions during the late Cenozoic (Figs. 7 and 8). Such a late Cenozoic cooling phase is widely recognized in the Tien Shan and reflects the onset of modern mountain building and associated basement denudation related to the ongoing indentation of the Indian plate into Eurasia. Although some major structures in the Tien Shan have been reactivated since the early Eocene (e.g. Glorie et al., 2011b), the building of the modern Tien Shan is generally believed to have started in the Oligocene-early Miocene, and exhumation was widespread from the Miocene onwards (e.g. Bullen et al., 2001, 2003; Buslov et al., 2008; De Grave et al., 2013; Jolivet et al., 2010; Macaulay et al., 2013, 2014; Sobel and Dumitru, 1997; Sobel et al., 2006; Yu et al., 2014). For example, Bullen et al. (2001) reported AFT ages between 20 and 10 Ma for the Kyrgyz Range, in the northern Kyrgyz Tien Shan. Also De Grave et al. (2013) and Macaulay et al. (2014) confirmed that in the Kyrgyz northern Tien Shan increased exhumation occurred between 15 and $5 \mathrm{Ma}$, and that the mountain ranges south of the Issyk Kul Basin deformed out-of-sequence, related to inherited structural weak zones. Magnetostratigraphic studies also underscore that the onset of the development of the modern Tien Shan initiated during the Miocene (Charreau et al., 2006, 2009). In the Altai region, late Cenozoic reactivation seems to start in the Miocene, with clear intensification in the Pliocene, and reflects in an analogous manner the initiation of the construction of the modern Altai Mountains (De Grave and Van den haute, 2002; Vassallo et al., 2007; Yuan et al., 2006).

After a period of minor sedimentation during the Paleogene, coarser clastic and thicker sedimentary piles are recognized since the MioPliocene in the Junggar, Issyk-Kul and Chu basins (Cobbold et al., 1993; De Grave et al., 2013; Q. Wang et al., 2009; Wang et al., 2001). Likewise, in the IBB, sedimentation became more widespread since the Neogene (Kober et al., 2013; Lucas et al., 1997, 2000). During the middle Miocene, a large lake/playa system existed in the center of the IBB (Kober et al., 2013). Up to then, sedimentation in the IBB was accompanied by local normal faulting. These normal faults became reactivated as reverse or strike-slip faults since the middle-late Miocene (Kober et al., 2013). Since the Plio-Pleistocene, coarser detrital sediments are deposited in the IBB (Kober et al., 2013; Lucas et al., 1997, 2000). Our AFT results are in agreement with these findings and confirm that more shortening and deformation took place in the IBB since the Miocene.

A topographic profile from Almaty (SE Kazakhstan) to Cholpon-Ata (NE Kyrgyzstan), crosscutting the Trans-Ili and Kungey Ranges, is given in Fig. 9. AFT data shown for this transect is based partly on samples from De Grave et al. (2013) (ALMA03-1/2/3, TS-04, TS-06 to TS-12), and partly on samples from this study (11-27, 11-28). The ALMA03-1/2/ 3 samples at the northern side of the Trans-Ili Range show a normal age-elevation relationship, with AFT ages ranging from 71 to $23 \mathrm{Ma}$. Samples TS-06 to TS-12 at the southern flank of the Kungey Range also show a normal age-elevation relationship, but AFT ages now range from 147 to $116 \mathrm{Ma}$ (De Grave et al., 2013). This age-offset between the two groups of samples is probably linked to the existence of active E-W oriented faults (Abdrakhmatov et al., 2002; Buslov et al., 2003a; Delvaux et al., 2001, 2013; Selander et al., 2012; Torizin et al., 2009) (Figs. 2, 6 and 9). Samples 11-27 and 11-28 - with Miocene AFT ages - are located close to the Trans-Ili or Zailisky Fault (ZF), which merge with the Chon-Kemin-Chilik Fault (CKCF) at depth (Delvaux et al., 2001; Torizin et al., 2009). Based on the seismic density map of Torizin et al. (2009), most seismicity in the Trans-Ili Range occurs around the Trans-Ili Fault (ZF), followed by the Karakunug-Almaty Fault (KAF) and the CKCF respectively, whereas south of the CKCF, in the Kungey Range, the seismic activity is less outspoken (Fig. 9).
The ALMA03-1/2/3, 11-27 and 11-28 samples are located in this high seismicity zone, close to where the largest seismic events of the region occurred (Verny earthquake in $1887(\mathrm{M}=7.3)$; Kemin earthquake in 1911 ( $M=8.2)$ ) (Abdrakhmatov et al., 2002; Delvaux et al., 2001; Torizin et al., 2009) (Fig. 9). Hence, late Cenozoic fault activity is probably responsible for the rapid and intense basement denudation, resulting in Miocene AFT ages in close vicinity of the ZF and KAF systems (Fig. 9). In comparison, in the Terskey Range, south of the Issyk-Kul Basin, a few similar late Oligocene to Miocene AFT ages are reported often in the vicinity of fault zones (De Grave et al., 2013; Macaulay et al., 2014). Furthermore, in the Chinese and southern Kyrgyz Tien Shan, similar Neogene AFT ages were documented in the vicinity of major E-W trending fault systems (e.g. Dumitru et al., 2001; Glorie et al., 2011b; W. Yang et al., 2014). Hence, denudation in the late Cenozoic seems to be at least partially controlled by fault activity.

\section{Conclusions}

Based on the geo- and thermochronological results, the following conclusions can be drawn for the Ili-Balkhash basement of SE Kazakhstan:

(1) Eight magmatic basement samples reveal zircon U-Pb crystallization ages between 350 and $260 \mathrm{Ma}$, spanning the Carboniferous to Permian time period. The Carboniferous ( 350-320 Ma) crystallization ages can be related to subduction of the Junggar-Balkhash Ocean and subsequent building of the Balkhash-Ili magmatic belt, whereas the early ( 296-297 Ma) and late ( $258 \mathrm{Ma})$ Permian ages probably correspond to collisional and post-collisional magmatism in the context of the late Paleozoic final amalgamation of the ancestral Central Asian Orogenic Belt.

(2) Apatite fission track ages and thermal history models fit into the thermochronological framework of the adjoining Tien Shan and Altai regions. Since the final amalgamation of the ancestral CAOB in the Permian, the study area was subjected to late Mesozoic and late Cenozoic reactivation periods.

(3) The predominantly Cretaceous AFT ages and thermal history models of the Ili-Balkhash basement point to a distinct late Mesozoic cooling period associated with basement denudation. The Cimmerian collisions at the southern Eurasian margin and possibly the Mongol-Okhotsk Orogeny in SE Siberia are envisaged as main tectonic drives for this late Mesozoic reactivation period. The variation in timing of the late Mesozoic cooling paths (and AFT ages) can be attributed to distinct tectonic movements and differences in exhumation rate between particular basement blocks.

(4) After a late Mesozoic reactivation episode, a tectonic stable period is recognized in the AFT thermal history models (slow cooling paths) during the Paleogene. This is in agreement with the nearly lack of sedimentary deposits and development of a regional peneplain during the Paleogene in SE Kazakhstan and adjoining regions.

(5) Late Cenozoic AFT cooling started around the late OligoceneMiocene and reflects the onset of modern mountain building and denudation in SE Kazakhstan. Along the active Trans-Ili Fault in the Kazakh Tien Shan, two Miocene AFT ages ( 17 and $10 \mathrm{Ma}$ ) were obtained. This modern denudation is also expressed by the marked change towards coarser clastic sedimentary deposits in the area since the middle Miocene and can be explained as a far-field effect of the ongoing indentation of the Indian plate into Eurasia.

Supplementary data to this article can be found online at http://dx. doi.org/10.1016/j.tecto.2015.06.014. 


\section{Acknowledgments}

This research was supported by the DARIUS program. Stijn Glorie's contribution was supported by the Australian Research Council grant DP150101730 and forms TraX Record \#307. We are indebted to Dr. Guido Vittiglio and Bart Van Houdt for their help with irradiations and neutron dosimetry at the Belgian Nuclear Research Centre in Mol (SCK-CEN, BR1 facility) and to Dr. Vladislav Batalev and Prof. Dr. Neil Davies for their help during the field expedition. We are also very grateful to Ann-Eline Debeer for her assistance in our laboratory in Ghent. Reviews of the original manuscript by Dr. Marc Jolivet and Dr. Jiyuan Yin were very helpful and contributed to this final version of the manuscript.

\section{References}

Abdrakhmatov, K.Ye., Aldazhanov, S.A., Hager, B.H., Hamburger, M.W., Herring, T.A Kalabaev, K.B., Makarov, V.I., Molnar, P., Panasyuk, S.V., Prilepin, M.T., Reilinger, R.E. Sadybakasov, I.S., Souter, B.J., Trapeznikov, Yu.A., Tsurkov, V.Ye., Zubovich, A.V. 1996. Relatively recent construction of the Tien Shan inferred from GPS measurements of present-day crustal deformation. Nature 384, 450-453.

Abdrakhmatov, K.Y., Djanuzakov, K.D., Delvaux, D., 2002. Active tectonics and seismic hazard of the Issyk-Kul basin in the Kyrgyz Tian-Shan. In: Klerkx, J., Imanackunov, B. (Eds.), Lake Issyk-Kul: Its natural environment. Kluwer Academic Publishers, Dordrecht, pp. 147-160

Abrajevitch, A., Van der Voo, R., Levashova, N.M., Bazhenov, M.L., 2007. Paleomagnetic constraints on the paleogeography and oroclinal bending of the Devonian volcanic arc in Kazakhstan. Tectonophysics 441, 67-84.

Abrajevitch, A., Van der Voo, R., Bazhenov, M.L., Levashova, N.M., McCausland, P.J.A., 2008. The role of the Kazakhstan orocline in the late Paleozoic amalgamation of Eurasia. Tectonophysics 455, 61-76.

Alexeiev, D.V., Ryazantsev, A.V., Kröner, A., Tretaykov, A.A., Xia, X., Liu, D.Y., 2011. Geochemical data and zircon ages for rocks in a high-pressure belt of Chu-Yili Mountains, southern Kazakhstan: implications for the earliest stages of accretion in Kazakhstan and the Tienshan. J. Asian Earth Sci. 42, 805-820.

Allen, M.B., Şengör, A.M.C., Natal'in, B.A., 1995. Junggar, Turfan and Alakol basins as Late Permian to Early Triassic extensional structures in a sinistral shear zone in the Altaid orogenic collage, Central Asia. J. Geol. Soc. Lond. 152 (2), 327-338.

Allen, M.B., Alsop, G.I., Zhemchuzhnikov, V.G., 2001. Dome and basin refolding and transpressive inversion along the Karatau fault System, southern Kazakstan. J. Geol. Soc. Lond. 158, 83-95.

Barbarand, J., Carter, A., Wood, I., Hurford, T., 2003. Compositional and structural control of fission-track annealing in apatite. Chem. Geol. 198, 107-137.

Bazhenov, M.L., Levashova, N.M., Degtyarev, K.E., Van der Voo, R., Abrajevitch, A.V. McCausland, P.J.A., 2012. Unraveling the early-middle Paleozoic paleogeography of Kazakhstan on the basis of Ordovician and Devonian paleomagnetic results. Gondwana Res. 22, 974-991.

Biske, Y.S., Konopelko, D.L., Seltmann, R., 2013. Geodynamics of Late Paleozoic Magmatism in the Tien Shan and Its Framework. Geotectonics 47, 291-309.

Bullen, M.E., Burbank, D.W., Garver, J.I., Abdrakhmatov, K.Ye., 2001. Late Cenozoic tectonic evolution of the northwestern Tien Shan: new age estimates for the initiation of mountain building. GSA Bull. 113 (12), 1544-1559.

Bullen, M.E., Burbank, D.W., Garver, J.I., 2003. Building the Northern Tien Shan: integrated thermal, structural, and topographic constraints. J. Geol. 111 (2), 149-165.

Buslov, M.M., 2011. Tectonics and geodynamics of the Central Asian Foldbelt: the role of Late Paleozoic large-amplitude strike-slip faults. Russ. Geol. Geophys. 52, 52-71.

Buslov, M.M., Klerkx, J., Abdrakhmatov, K., Delvaux, D., Batalev, V.Y., Kuchai, O.A., Dehandschutter, B., Muraliev, A., 2003a. Recent strike-slip deformation of the northern Tien Shan. In: Storti, F., Holdsworth, R.E., Salvini, F. (Eds.), Intraplate Strike-Slip Deformation Belts. Geological Society, London, Special Publications 210, pp. 53-64.

Buslov, M.M., Watanabe, T., Smirnova, L.V., Fujiwara, I., Iwata, K., De Grave, J., Semakov, N.N., Travin, A.V., Kir'yanova, A.P., Kokh, D.A., 2003b. Role of strike-slip faulting in Late Paleozoic-Early Mesozoic tectonics and geodynamics of the Altai-Sayan and East Kazashstan Regions. Russ. Geol. Geophys. 44, 49-75.

Buslov, M.M., Watanabe, T., Fujiwara, Y., Iwata, K., Smirnova, L.V., Safonova, I.Yu., Semakov, N.N., Kiryanova, A.P., 2004. Late Paleozoic faults of the Altai region, Central Asia: tectonic pattern and model of formation. J. Asian Earth Sci. 23, 655-671.

Buslov, M.M., De Grave, J., Bataleva, E.A.V., Batalev, V.Y., 2007. Cenozoic tectonic and geodynamic evolution of the Kyrgyz Tien Shan Mountains: a review of geological, thermochronological and geophysical data. J. Asian Earth Sci. 29, 205-214.

Buslov, M.M., Kokh, D.A., De Grave, J., 2008. Mesozoic-Cenozoic tectonics and geodynamics of Altai, Tien Shan, and Northern Kazakhstan, from apatite fissiontrack data. Russ. Geol. Geophys. 49, 648-654.

Buslov, M.M., Geng, H., Travin, A.V., Otgonbaatar, D., Kulikova, A.V., Chen, M., Glorie, S. Semakov, N.N., Rubanova, E.S., Abildaeva, M.A., Voitishek, E.E., Trofimova, D.A. 2013. Tectonics and geodynamics of Gorny Altai and adjacent structures of the Altai-Sayan folded area. Russ. Geol. Geophys. 54, 1250-1271.

Campbell, G.E., Walker, R.T., Abdrakhmatov, K., Schwenninger, J.L., Jackson, J., Elliott, J.R Copley, A., 2013. The Dzhungarian fault: Late Quaternary tectonics and slip rate of a major right-lateral strike-slip fault in the northern Tien Shan region. J. Geophys. Res. Solid Earth 118, 5681-5698.

Carlson, W.D., Donelick, R.A., Ketcham, R.A., 1999. Variability of apatite fission-track annealing kinetics: I. Experimental results. Am. Mineral. 84, 1213-1223.

Charreau, J., Gilder, S., Chen, Y., Dominguez, S., Avouac, J.-P., Sen, S., Jolivet, M., Li, Y., Wang, W., 2006. Magnetostratigraphy of the Yaha section, Tarim basin (China): 11 Ma acceleration in erosion and uplift of the Tianshan Mountains. Geology 34 (3), 181-184.

Charreau, J., Chen, Y., Gilder, S., Barrier, L., Dominguez, S., Augier, R., Sen, S., Avouac, J.-P., Gallaud, A., Graveleau, F., Wang, Q., 2009. Neogene uplift of the Tien Shan Mountains observed in the magnetic record of the Jingou River section (northwest China). Tectonics 28, TC2008.

Charvet, J., Shu, L., Laurent-Charvet, S., 2007. Paleozoic structural and geodynamic evolution of eastern Tianshan (NW China): welding of the Tarim and Junggar plates. Episodes 30, 162-186.

Chen, B. Jahn, B.-M., 2004. Genesis of post-collisional granitoids and basement nature of the Junggar Terrane, NW China: Nd-Sr isotope and trace element evidence. J. Asian Earth Sci. 23, 691-703

Chen, X., Qu, W., Han, S., Eleonora, S., Yang, N., Chen, Z., Zeng, F., Du, A., Wang, Z., 2010. Re-Os geochronology of $\mathrm{Cu}$ and $\mathrm{W}$-Mo deposits in the Balkhash metallogenic belt, Kazakhstan and its geological significance. Geosci. Front. 1, 115-124.

Chen, X.H., Wang, Z.H., Chen, Z.L., Han, S.Q., Seitmuratova, E., Yang, Y., Ye, B.Y., Chen, W., 2012. Geochronological constraints on skarn copper metallogenesis of the large-scale Sayak ore field, Kazakhstan, Central Asia. Acta Petrol. Sin. 28, 1981-1994 (in Chinese with English abstract)

Chen, X., Seitmuratova, E., Wang, Z., Chen, Z., Han, S., Li, Y., Yang, Y., Ye, B., Shi, W., 2014. SHRIMP U-Pb and Ar-Ar geochronology of major porphyry and skarn Cu deposits in the Balkhash Metallogenic Belt, Central Asia, and geological implications. J. Asian Earth Sci. 79, 723-740.

Cherniak, D., Watson, E., 2003. Diffusion in zircon. In: Hanchar, J., Hoskin, P. (Eds.), Zircon. Reviews in Mineralogy and Geochemistry 53, pp. 113-139.

Choulet, F., Chen, Y., Wang, B., Faure, M., Cluzel, D., Charvet, J., Lin, W., Xu, B., 2011. Late Paleozoic paleogeographic reconstruction of Western Central Asia based upon paleomagnetic data and its geodynamic implications. J. Asian Earth Sci. 42, 867-884.

Choulet, F., Faure, M., Cluzel, D., Chen, Y., Lin, W., Wang, B., 2012. From oblique accretion to transpression in the evolution of the Altaid collage: new insights from West Junggar, northwestern China. Gondwana Res. 21, 530-547.

Choulet, F., Chen, Y., Cogné, J.P., Rabillard, A., Wang, B., Lin, W., Faure, M., Cluzel, D., 2013. First Triassic palaeomagnetic constraints from Junggar (NW China) and their implications for the Mesozoic tectonics in Central Asia. J. Asian Earth Sci. 78, 371-394.

Cobbold, P.R., Davy, P., Gapais, D., Rossello, E.A., Sadybakasov, E., Thomas, J.C., Tondji Biyo, J.J., de Urreiztieta, M., 1993. Sedimentary basins and crustal thickening. Sediment. Geol. 86, 77-89.

Cobbold, P.R., Sadybakasov, E., Thomas, J.C., 1994. Cenozoic transpression and basin development, Kyrghyz Tienshan, Central Asia. In: Roure, F., Ellouz, N., Shein, V.S., Skvortsov, I. (Eds.), Geodynamic Evolution of Sedimentary Basins. International Symposium, Moscow, pp. 181-202.

Cogné, J.-P., Kravchinsky, V.A., Halim, N., Hankard, F., 2005. Late Jurassic-Early Cretaceous closure of the Mongol-Okhotsk Ocean demonstrated by new Mesozoic palaeomagnetic results from the Trans-Baïkal area (SE Siberia). Geophys. J. Int. 163, 813-832.

Corfu, F., Hanchar, J.M., Hoskin, P.W.O., Kinny, P., 2003. Atlas of zircon textures. Rev. Mineral. Geochem. 53, 469-500.

De Corte, F., Bellemans, F., Van den haute, P., Ingelbrecht, C., Nicholl, C., 1998. A new U doped Glass Certified by the European Commission for the Calibration of FissionTrack Dating. In: Van den haute, P., De Corte, F. (Eds.), Advances in fission-track geochronology. Kluwer Academic Publishers, Dordrecht, pp. 67-78.

De Grave, J., Van den haute, P., 2002. Denudation and cooling of the Lake Teletskoye Region in the Altai Mountains (South Siberia) as revealed by apatite fission-track thermochronology. Tectonophysics 349, 145-159.

De Grave, J., Buslov, M.M., Van den haute, P., 2007. Distant effects of India-Eurasia convergence and Mesozoic intracontinental deformation in Central Asia: constraints from apatite fission-track thermochronology. J. Asian Earth Sci. 29, 188-204.

De Grave, J., Van den haute, P., Buslov, M.M., Dehandschutter, B., Glorie, S., 2008. Apatite fission-track thermochronology applied to the Chulyshman Plateau, Siberian Altai Region. Radiat. Meas. 43, 38-42.

De Grave, J., Buslov, M.M., Van den haute, P., Metcalf, J., Dehandschutter, B., McWilliams, M.O., 2009. Multi-method chronometry of the Teletskoye graben and its basement, Siberian Altai Mountains: new insights on its thermo-tectonic evolution. From: Lisker, F., Ventura, B., Glasmacher, U.A. Thermochronological methods: from paleotemperature constraints to landscape evolution models. Geol. Soc. Lond., Spec. Publ. 324, 237-259.

De Grave, J., Glorie, S., Buslov, M.M., Izmer, A., Fournier-Carrie, A., Elburg, M., Batalev, V.Yu., Vanhaeke, F., Van den haute, P., 2011a. The thermo-tectonic history of the Song-Kul Plateau, Kyrgyz Tien Shan: constraints by apatite and titanite thermochronometry and zircon U/Pb dating. Gondwana Res. 20, 745-763.

De Grave, J., Glorie, S., Zhimulev, F.I., Buslov, M.M., Elburg, M., Vanhaecke, F., Van den haute, P., 2011b. Emplacement and exhumation of the Kuznetsk-Alatau basement (Siberia): implications for the tectonic evolution of the Central Asian Orogenic Belt and sediment supply to the Kuznetsk, Minusa and West Siberian Basins. Terra Nova 23, 248-256.

De Grave, J., Glorie, S., Ryabinin, A., Zhimulev, F., Izmer, A., Buslov, M.M., Elburg, M., Vanhaeke, F., Van den haute, P., 2012. Late Palaeozoic and Meso-Cenozoic tectonic evolution of the Southern Kyrgyz Tien Shan: constraints from multi-method thermochronology in the Trans-Alai, Turkestan-Alai Section and the Southeastern Ferghana Basin. J. Asian Earth Sci. 44, 149-168.

De Grave, J., Glorie, S., Buslov, M.M., Stockli, D.F., McWilliams, M.O., Batalev, V.Y., Van den haute, P., 2013. Thermo-tectonic history of the Issyk-Kul basement (Kyrgyz Northern Tien Shan, Central Asia). Gondwana Res. 23, 998-1020. 
Degtyarev, K.E., 2011. Tectonic evolution of Early Paleozoic Island-Arc systems and continental crust formation in the Caledonides of Kazakhstan and the North Tien Shan. Geotectonics 45, 23-50.

Degtyarev, K.E., Shatagin, K.N., Kotov, A.B., Sal'nikova, E.B., Luchitskaya, M.V., Yakovleva, S.Z., Plotkina, Y.U.V., Fedoseenko, A.M., 2006. Early Paleozoic Granitoids of the AqtauDzungar microcontinent (Central Kazakhstan). Dokl. Earth Sci. 411, 1204-1208.

Delvaux, D., Abdrakhmatov, K.E., Lemzin, I.N., Strom, A.L., 2001. Landslides and surface breaks of the $1911 \mathrm{M}_{\mathrm{s}} 8.2$ Kemin earthquake (Kyrgyzstan). Russ. Geol. Geophys. 42, 1583-1592.

Delvaux, D., Cloetingh, S., Beekman, F., Sokoutis, D., Burov, E., Buslov, M.M., Abdrakhmatov, K.E., 2013. Basin evolution in a folding lithosphere: Altai-Sayan and Tien Shan belts in Central Asia. Tectonophysics 602, 194-222.

Dobretsov, N.L., 2011. Early Paleozoic tectonics and geodynamics of Central Asia: role of mantle plumes. Russ. Geol. Geophys. 52, 1539-1552.

Dobretsov, N.L., Buslov, M.M., 2007. Late Cambrian-Ordovician tectonics and geodynamics of Central Asia. Russ. Geol. Geophys. 48, 71-82.

Donelick, R.A., Ketcham, R.A., Carlson, W.D., 1999. Variability of apatite fission-track annealing kinetics: II. Crystallographic orientation effects. Am. Mineral. 84 (9), 1224-1234.

Donelick, R., O'Sullivan, P., Ketcham, R., 2005. Apatite fission-track analysis. Rev. Mineral. Geochem. 58, 49-94.

Dong, Y., Zhang, G., Neubauer, F., Liu, X., Hauzenberger, C., Zhou, D., Li, W., 2011. Syn- and post-collisional granitoids in the Central Tianshan orogen: geochemistry, geochronology and implications for tectonic evolution. Gondwana Res. 20, 568-581.

Dumitru, T.A., Zhou, D., Chang, E.Z., Graham, S.A., 2001. Uplift, exhumation, and deformation in the Chinese Tian Shan. Geol. Soc. Am. Mem. 194, 71-99.

Feng, Y., Coleman, R.G., Tilton, G., Xiao, X., 1989. Tectonic evolution of the West Junggar region, Xinjiang, China. Tectonics 8, 729-752

Filippova, I.B., Bush, V.A., Didenko, A.N., 2001. Middle Paleozoic subduction belts: the leading factor in the formation of the Central Asian fold-and-thrust belt. Russ. J. Earth Sci. 3, 405-426.

Galbraith, R.F., 1990. The radial plot: graphical assessment of spread in ages. Nucl. Tracks Radiat. Meas. 17, 207-214.

Gallagher, K., 2012. Transdimensional inverse thermal history modeling for quantitative thermochronology. J. Geophys. Res. Solid Earth 117 (B2).

Gao, R., Xiao, L., Pirajno, F., Wang, G.-C., He, X.-X., Yang, G., Yan, S.-W., 2014. CarboniferousPermian extensive magmatism in the West Junggar, Xinjiang, northwestern China: its geochemistry, geochronology, and petrogenesis. Lithos 204, 125-143.

Geng, H., Sun, M., Yuan, C., Xiao, W., Xian, W., Zhao, G., Zhang, L., Wong, K., Wu, F., 2009. Geochemical, $\mathrm{Sr}-\mathrm{Nd}$ and zircon $\mathrm{U}-\mathrm{Pb}-\mathrm{Hf}$ isotopic studies of Late Carboniferous magmatism in the West Junggar, Xinjiang: implications for ridge subduction? Chem. Geol. 266, 364-389.

Geng, H., Sun, M., Yuan, C., Zhao, G., Xiao, W., 2011. Geochemical and geochronological study of early Carboniferous volcanic rocks from the West Junggar: petrogenesis and tectonic implications. J. Asian Earth Sci. 42, 854-866.

Gleadow, A.J.W., Duddy, I.R., Green, P.F., Lovering, J.F., 1986. Confined fission track lengths in apatite: a diagnostic tool for thermal history analysis. Contrib. Mineral. Petrol. 94 405-415.

Glorie, S., De Grave, J., 2015. Exhuming the Meso-Cenozoic Kyrgyz Tian Shan and Siberian Altai-Sayan: a review based on low-temperature thermochronology. Geosci. Front. http://dx.doi.org/10.1016/j.gsf.2015.04.003 (in press).

Glorie, S., De Grave, J., Buslov, M.M., Elburg, M.A., Stockli, D.F., Gerdes, A., Van den haute, P., 2010. Multi-method chronometric constraints on the evolution of the Northern Kyrgyz Tien Shan granitoids (Central Asian Orogenic Belt): from emplacement to exhumation. J. Asian Earth Sci. 38, 131-146.

Glorie, S., De Grave, J., Buslov, M.M., Zhimulev, F.I., Izmer, A., Vandoorne, W., Ryabinin, A., Van den haute, P., Vanhaecke, F., Elburg, M., 2011a. Formation and Palaeozoic evolution of the Gorny-Altai-Altai-Mongolia suture zone (South Siberia): zircon U/Pb constraints on its igneous record. Gondwana Res. 20, 465-484.

Glorie, S., De Grave, J., Buslov, M.M., Zhimulev, F.I., Stockli, D.F., Batalev, V.Yu., Izmer, A., Van den haute, P., Vanhaecke, F., Elburg, M.A., 2011b. Thermotectonic history of the Kyrgyz South Tien Shan (Atbashi-Inylchek) suture zone: the role of inherited structures during deformation-propagation. Tectonics 30, TC6016.

Glorie, S., De Grave, J., Buslov, M.M., Zhimulev, F.I., Elburg, M.A., Van den haute, P., 2012a. Structural control on Meso-Cenozoic tectonic reactivation and denudation in the Siberian Altai: insights from multi-method thermochronometry. Tectonophysics $544-545,75-92$

Glorie, S., De Grave, J., Delvaux, D., Buslov, M.M., Zhimulev, F.I., Van den haute, P., 2012b. Tectonic history of the Irtysh shear zone (NE Kazakhstan): new constraints from zircon $\mathrm{U} / \mathrm{Pb}$ dating, apatite fission track dating and paleostress analysis. J. Asian Earth Sci. 45, 138-149.

Glorie, S., Zhimulev, F.I., Buslov, M.M., Andersen, T., Plavsa, D., Izmer, A., Vanhaecke, F., De Grave, J., 2015. Formation of the Kokchetav subduction-collision zone (northern Kazakhstan): insights from zircon U-Pb and Lu-Hf isotope systematics. Gondwana Res. 27, 424-438.

Golonka, J., 2004. Plate tectonic evolution of the southern margin of Eurasia in the Mesozoic and Cenozoic. Tectonophysics 381, 235-273.

Green, P.F., Duddy, I.R., Gleadow, A.JW., Tingate, P.R., Laslett, G.M., 1986. Thermal annealing of fission tracks in apatite 1.A qualitative description. Chem. Geol. 59, 237-253.

Guo, L.S., Liu, Y.L., Wang, Z.H., Song, D., Xu, F.J., Su, L., 2010. The zircon U-Pb LA-ICP-MS geochronology of volcanic rocks in Baogutu areas, western Junggar. Acta Petrol. Sin. 26, 471-477 (in Chinese with English abstract).

Halim, N., Cogné, J.P., Chen, Y., Atasiei, R., Besse, J., Courtillot, V., Gilder, S., Marcoux, J., Zhao, R.L., 1998. New Cretaceous and Early Tertiary paleomagnetic results from Xining-Lanzhou basin, Kunlun and Qiangtang blocks, China: implications on the geodynamic evolution of Asia. J. Geophys. Res. 103, 025-045.
Han, B.F., Ji, J.Q., Song, B., Chen, L.H., Zhang, L., 2006. Late Paleozoic vertical growth of continental crust around the Junggar Basin, Xinjiang, China (Part I): timing of postcollisional plutonism. Acta Petrol. Sin. 22, 1077-1086.

Han, B.-F., Guo, Z.-J., Zhang, Z.-C., Zhang, L., Chen, J.-f., Song, B., 2010. Age, geochemistry, and tectonic implications of a late Paleozoic stitching pluton in the North Tian Shan suture zone, western China. Geol. Soc. Am. Bull. 122, 627-640.

Han, B.-F., He, G.-Q., Wang, X.-C., Guo, Z.-J., 2011. Late Carboniferous collision between the Tarim and Kazakhstan-Yili terranes in the western segment of the South Tian Shan Orogen, Central Asia, and implications for the Northern Xinjiang, western China. Earth Sci. Rev. 109, 74-93.

Heinhorst, J., Lehmann, B., Ermolov, P., Serykh, V., Zhurutin, S., 2000. Paleozoic crusta growth and metallogeny of Central Asia: evidence from magmatic-hydrothermal ore systems of Central Kazakhstan. Tectonophysics 328, 69-87.

Hendrix, M.S., Graham, S.A., Carroll, A.R., Sobel, E.R., McKnight, C.L., Schulein, B.J., Wang, Z., 1992. Sedimentary record and climatic implications of recurrent deformation in the Tien Shan: evidence from Mesozoic strata of the north Tarim, south Junggar, and Turpan basins, Northwest China. Geol. Soc. Am. Bull. 104 (1), 53-79.

Hendrix, M.S., Dumitru, T.A., Graham, S.A., 1994. Late Oligocene-Early Miocene unroofing in the Chinese Tien Shan - an early effect of the India-Asian collision. Geology 22 487-490.

Hoskin, P.W.O., 2000. Patterns of chaos: fractal statistics and the oscillatory chemistry of zircon. Geochim. Cosmochim. Acta 64, 1905-1923.

Hurford, A.J., 1990. Standardization of fission track dating calibration: recommendation by the Fission Track Working Group of the I.U.G.S. Subcommission on Geochronology. Chem. Geol. Isot. Geosci. 80, 171-178.

Institute of Geology, Chinese Academy of Geological Sciences (IGCAGS) (2006) 1: 2500000 Geological Map of Western China and adjacent regions. Geological Publishing House, Beijing (in Chinese). Chief compiler: Li Tingdong.

Jackson, S.E., Pearson, N.J., Griffin, W.L., Belousova, E., 2004. The application of lase ablation inductively coupled plasma mass spectrometry to in-situ U-Pb zircon geochronology. Chem. Geol. 211, 47-69.

Jolivet, M., 2015. Mesozoic tectonic and topographic evolution of Central Asia and Tibet: a preliminary synthesis. Geol. Soc. Lond. Spec. Publ. (in press).

Jolivet, M., Dominguez, S., Charreau, J., Chen, Y., Li, Y.G., Wang, Q.C., 2010. Mesozoic and Cenozoic tectonic history of the central Chinese Tian Shan: reactivated tectonic structures and active deformation. Tectonics 29, TC6019.

Jolivet, M., Arzhannikov, S., Arzhannikova, A., Chauvet, A., Vassallo, R., Braucher, R., 2013a Geomorphic Mesozoic and Cenozoic evolution in the Oka-Jombolok region (East Sayan ranges, Siberia). J. Asian Earth Sci. 62, 117-132.

Jolivet, M., Heilbronn, G., Robin, C., Barrier, L., Bourquin, S., Guo, Zh., Jia, Y., Guerit, L., Yang, W Fu, B., 2013b. Reconstructing the Late Palaeozoic-Mesozoic topographic evolution of the Chinese Tian Shan: available data and remaining uncertainties. Adv. Geosci. 1, 1-12.

Jolivet, M., Bourquin, S., Heilbronn, G., Robin, C., Barrier, L., Dabard, M.-P., Jia, Y., De Pelsmaeker, E., Fu, B., 2015. The Upper Jurassic-Lower Cretaceous alluvial fan deposits of the Kalaza Formation (Central Asia): tectonic pulse or increased aridity? Geol. Soc. Lond. Spec. Publ. (in press).

Kapp, P., Murphy, M.A., Yin, A., Harrison, T.M., Ding, L., Guo, J., 2003. Mesozoic and Cenozoic tectonic evolution of the Shiquanhe area of western Tibet. Tectonics 22, 1029.

Ketcham, R.A., 2005. Forward and inverse modeling of low-temperature thermochronometry data. Rev. Mineral. Geochem. 58, 275-314.

Ketcham, R.A., Donelick, R.A., Carlson, W.D., 1999. Variability of apatite fission-track annealing kinetics: III. Extrapolation to geological time scales. Am. Mineral. 84 (9), 1235-1255.

Ketcham, R.A., Donelick, R.A., Donelick, M.B., 2000. AFTSolve: a program from multikinetic modeling of apatite fission-track data. Geol. Mater. Res. 2, 1-32.

Ketcham, R.A., Carter, A., Donelick, R.A., Barbarand, J., Hurford, A.J., 2007. Improved modeling of fission-track annealing in apatite. Am. Mineral. 92, 799-810.

Kober, M., Seib, N., Kley, J., Voigt, T., 2013. Thick-skinned thrusting in the northern Tien Shan foreland, Kazakhstan: structural inheritance and polyphase deformation. Geol. Soc. Lond., Spec. Publ. 377, SP377.7.

Konopelko, D., Biske, G., Seltmann, R., Eklund, O., Belyatsky, B., 2007. Hercynian postcollisional A-type granites of the Kokshaal Range, Southern Tien Shan, Kyrgyzstan. Lithos 97, 140-160.

Korobkin, V.V., Buslov, M.M., 2011. Tectonics and geodynamics of the western Central Asian Fold Belt (Kazakhstan Paleozoides). Russ. Geol. Geophys. 52, 1600-1618.

Kröner, A., Hegner, E., Lehmann, B., Heinhorst, J., Wingate, M.T.D., Liu, D.Y., Ermelov, P., 2008 Palaeozoic arc magmatism in the Central Asian Orogenic Beld of Kazakhstan: SHRIMP zircon ages and whole-rock Nd isotopic systematics. J. Asian Earth Sci. 32, 118-130.

Kröner, A., Alexeiev, D.V., Rojas-Agramonte, Y., Hegner, E., Wong, J., Xia, X., Belousova E., Mikolaichuk, A.V., Seltmann, R., Liu, D., Kiselev, V.V., 2013. Mesoproterozoic (Grenville-age) terranes in the Kyrgyz North Tianshan: zircon ages and Nd-H isotopic constraints on the origin and evolution of basement blocks in the southern Central Asian Orogen. Gondwana Res. 23, 272-295.

Levashova, N.M., Mikolaichuk, A.V., McCausland, P.J.A., Bazhenov, M.L., Van der Voo, R. 2007. Devonian paleomagnetism of the North Tien Shan: implications for the middle-Late Paleozoic paleogeography of Eurasia. Earth Planet. Sci. Lett. 257, 104-120.

Levashova, N.M., Degtyarev, K.E., Bazhenov, M.L., 2012. Oroclinal bending of the Middle and Late Paleozoic Volcanic Belts in Kazakhstan: paleomagnetic evidence and geological implications. Geotectonics 46, 285-302.

Li, L., Chen, Z.L., Qi, W.X., Wang, S.X., Chen, X.H., Wu, Y.P., Gong, H.L., Wei, X.C., Yang, Y., Li, X.Z., 2008. Apatite fission track evidence for uplifting-exhumation processes of mountains surrounding the Junggar basin. Acta Petrol. Sin. 24, 1011-1020 (In Chinese with English abstract).

Li, G.-M., Cao, M.-J., Qin, K.-Z., Evans, N.J., McInnes, B.I.A., Liu, Y.-S., 2014. Thermal-tectonic history of the Baogutu porphyry Cu deposit, West Junggar as constrained from zircon $\mathrm{U}-\mathrm{Pb}$, biotite $\mathrm{Ar} / \mathrm{Ar}$ and zircon/apatite (U-Th)/He dating. J. Asian Earth Sci. 79, 741-758. 
Liu, D., Guo, Z., Jolivet, M., Cheng, F., Song, Y., Zhang, Z., 2014. Petrology and geochemistry of Early Permian volcanic rocks in South Tian Shan, NW China: implications for the tectonic evolution and Phanerozoic continental growth. Int. J. Earth Sci. 103, 737-756.

Lucas, S.G., Bayshashov, B.U., Tyutkova, L.A., Zhamangara, A.K., Aubekerov, B.Z., 1997. Mammalian biochronology of the Paleogene-Neogene boundary at Aktau Mountain, eastern Kazakhstan. Paläontol. Z. 71, 305-314.

Lucas, S.G., Aubekerov, B.Z., Dzhamangaraeva, A.K., Bayshashov, B.U., Tyutkova, L.A., 2000 Cenozoic lacustrine deposits of the Ili Basin, southeastern Kazakhstan. In: Kelts, K.R. (Ed.), Lake Basins Through Space and Time. American Association of Petroleum Geologists, Tulsa, pp. 59-64.

Ludwig, K., 2003. User's Manual for Isoplot 3.00, A Geochronological Toolkit for Microsoft Excel. Berkeley Geochronology Center Special, Publication v. 4.

Macaulay, E.A., Sobel, E.R., Mikolaichuk, A., Landgraf, A., Kohn, B., Stuart, F., 2013. Thermochronologic insights into Late Cenozoic deformation in the basement-cored Terskey Range Kyrgyz Tien Shan. Tectonics 32, 487-500.

Macaulay, E.A., Sobel, E.R., Mikolaichuk, A., Kohn, B., Stuart, F.M., 2014. Cenozoic deformation and exhumation history of the Central Kyrgyz Tien Shan. Tectonics 33, 135-165.

Metcalfe, I., 2013. Gondwana dispersion and Asian accretion: tectonic and palaeogeographic evolution of eastern Tethys. J. Asian Earth Sci. 66, 1-33.

Metelkin, D.V., Vernikovsky, V.A., Kazansky, A.Y., Wingate, M.T.D., 2010. Late Mesozoic tectonics of Central Asia based on paleomagnetic evidence. Gondwana Res. 18 $400-419$.

Metelkin, D.V., Vernikovsky, V.A., Kazansky, A.Yu., 2012. Tectonic evolution of the Siberian paleocontinent from the Neoproterozoic to the Late Mesozoic: paleomagnetic record and reconstructions. Russ. Geol. Geophys. 53, 675-688.

Novikov, I.S., 2013. Reconstructing the stages of orogeny around the Junggar basin from the lithostratigraphy of Late Paleozoic, Mesozoic and Cenozoic sediments. Russ. Geol. Geophys. 54, 138-152.

Ren, R., Han, B.-F., Ji, J.-O., Zhang, L., Xu, Z., Su, L., 2011. U-Pb age of detrital zircons from the Tekes River, Xinjiang, China, and implications for tectonomagmatic evolution of the South Tian Shan Orogen. Gondwana Res. 19, 460-470.

Roger, F., Jolivet, M., Malavieille, J., 2010. The tectonic evolution of the Songpan-Garzê (North Tibet) and adjacent areas from Proterozoic to Present: a synthesis. J. Asian Earth Sci. 39, 254-269.

Rolland, Y., Alexeiev, D., Kröner, A., Corsini, M., Loury, C., Monié, P., 2013. Late Palaeozoic to Mesozoic kinematic history of the Talas-Ferghana strike-slip fault (Kyrgyz West Tianshan) as revealed by ${ }^{40} \mathrm{Ar} /{ }^{39} \mathrm{Ar}$ dating of syn-kinematic white mica. J. Asian Earth Sci. 67-68, 76-92.

Selander, J., Oskin, M., Ormukov, C., Abdrakhmatov, K., 2012. Inherited strike-slip faults as an origin for basement-cored uplifts: example of the Kungey and Zailiskey Ranges, northern Tian Shan. Tectonics 31, TC4026.

Seltmann, R., Konopelko, D., Biske, G., Divaev, F., Sergeev, S., 2011. Hercynian postcollisional magmatism in the context of Paleozoic magmatic evolution of the Tien Shan orogenic belt. J. Asian Earth Sci. 42, 821-838.

Sengör, A.M.C., Natal'in, B.A., 1996. Paleotectonics of Asia: fragments of a synthesis. In: Yin, A., Harrison, T.M. (Eds.), The Tectonic Evolution of Asia. Cambridge University Press, New York, pp. 486-641.

Sengör, A.M.C., Natal'in, B.A., Burtman, V.S., 1993. Evolution of the Altaid tectonic collage and Paleozoic crustal growth in Eurasia. Nature 364 (6435), 299-307.

Shen, P., Shen, Y., Li, X.-H., Pan, H., Zhu, H., Meng, L., Dai, H., 2012. Northwestern Junggar Basin, Xiemisitai Mountains, China: a geochemical and geochronological approach. Lithos 140-141, 103-118.

Shen, P., Pan, H., Xiao, W., Chen, X., Seitmuratova, E., Shen, Y., 2013a. Two geodynamicmetallogenic events in the Balkhash (Kazakhstan) and the West Junggar (China): Carboniferous porphyry $\mathrm{Cu}$ and Permian greisen W-Mo mineralization. Int. Geol. Rev. 55, 1660-1687.

Shen, P., Xiao, W., Pan, H., Dong L., Li, C., 2013b. Petrogenesis and tectonic settings of the Late Carboniferous Jiamantieliek and Baogutu ore-bearing porphyry intrusions in the southern West Junggar, NW China. J. Asian Earth Sci. 75, 158-173.

Sláma, J., Kosler, D., Condon, D.J., Crowley, J.L., Gerdes, A., Hanchar, J.M., Horstwood, M.S.A Morris, G.A., Nasdala, L., Norberg, N., Schaltegger, U., Schoene, B., Tubrett, M.N., Whitehouse, M.J., 2008. Plesovice zircon - a new natural reference material for $\mathrm{U}-\mathrm{Pb}$ and $\mathrm{Hf}$ isotopic microanalysis. Chem. Geol. 249, 1-35.

Sobel, E.R., Dumitru, T.A., 1997. Thrusting and exhumation around the margins of the western Tarim basin during the India-Asia collision. J. Geophys. Res. 102, 5043-5063.

Sobel, E.R., Oskin, M., Burbank, D., Mikolaichuk, A., 2006. Exhumation of basement-cored uplifts: example of the Kyrgyz Range quantified with apatite fission track thermochronology. Tectonics 25, TC2008

Steiger, R.H., Jäger, E., 1977. Subcommission on geochronology: convention on the use of decay constants in geo- and cosmochronology. Earth Planet. Sci. Lett. 36, 359-362.

Tang, G.-J., Wang, O., Wyman, D., Sun, M., Li, Z.-X., Zhao, Z.-H., Sun, W.-D., Jia, X.-H., Jiang, Z.-Q., 2010. Geochronology and geochemistry of Late Paleozoic magmatic rocks in the Lamasu-Dabate area, northwestern Tianshan (west China): evidence for a tectonic transition from arc to post-collisional setting. Lithos 119, 393-411.

Thomas, J.C., Cobbold, P.R., Shein, V.S., Le Douaran, S., 1999. Sedimentary record of late Paleozoic to Recent tectonism in Central Asia - analysis of subsurface data from the Turan and Kazak domains. Tectonophysics 313, 243-263.

Tong, Y., Wang, T., Jahn, B.-M., Sun, M., Hong, D.-W., Gao, J.-F., 2014. Post-accretionary Permian granitoids in the Chinese Altai Orogen: geochronology, petrogenesis and tectonic implications. Am. J. Sci. 314, 80-109.

Torizin, J., Jentzsch, G., Malischewsky, P., Kley, J., Abakanov, N., Kurskeev, A., 2009. Rating of seismicity and reconstruction of the fault geometries in northern Tien Shan within the project "Seismic Hazard Assessment for Almaty”. J. Geodyn. 48, 269-278.

Van der Voo, R., Levashova, N.M., Skrinnik, L.I., Kara, T.V., Bazhenov, M.L., 2006. Late orogenic large-scale rotations in the Tien Shan and adjacent mobile belts in Kyrgyzstan and Kazakhstan. Tectonophysics 426, 335-360.
Vandoorne, W., De Grave, J., Glorie, S., Van den haute, P., 2011. The tectonic evolution of the Chuya-Kurai zone (Siberian Altai mountains) by means of multi-method chronology. Geol. Belg. 14, 289-292.

Vassallo, R., Jolivet, M., Ritz, J.-F., Braucher, R., Larroque, C., Sue, C., Todbileg, M., Javkhlanbold, D., 2007. Uplift age and rates of the Gurvan Bogd system (Gobi-Altay) by apatite fission track analysis. Earth Planet. Sci. Lett. 259, 333-346.

Vermeesch, P., 2009. RadialPlotter: a Java application for fission track, luminescence and other radial plots. Radiat. Meas. 44, 409-410.

Vincent, S.J., Allen, M.B., 2001. Sedimentary record of Mesozoic intracontinental deformation in the eastern Junggar Basin, north-west China: response to orogeny at the Asian margin. In: Hendrix, M.S., Davis, G.A. (Eds.), Palaeozoic and Mesozoic Tectonic Evolution of Central and Eastern Asia: from Continental Assembly to Intracontinental Deformation. Geol. Soc. Am. Mem., pp. 341-360.

Wagner, G.A., Van den haute, P., 1992. Fission Track-Dating. Kluwer Academic Publishers, Dordrecht (285 pp.).

Wang, S., He, L., Wang, J., 2001. Thermal regime and petroleum systems in Junggar basin, northwest China. Phys. Earth Planet. Inter. 126, 237-248.

Wang, B., Chen, Y., Zhan, S., Shu, L., Faure, M., Cluzel, D., Charvet, J., Laurent-Charvet, S., 2007. Primary Carboniferous and Permian paleomagnetic results from the Yili block (NW China) and their implications on the geodynamic evolution of Chinese Tianshan belt. Earth Planet. Sci. Lett. 263, 288-308.

Wang, B., Cluzel, D., Shu, L., Faure, M., Charvet, J., Chen, Y., Meffre, S., de Jong, K., 2009a. Evolution of calc-alkaline to alkaline magmatism through Carboniferous convergence to Permian transcurrent tectonics, western Chinese Tianshan. Int. J. Earth Sci. 98, $1275-1298$

Wang, Q., Li, S., Du, Z., 2009b. Differential uplift of the Chinese Tianshan since the Cretaceous: constraints from sedimentary petrography and apatite fission-track dating. Int. J. Earth Sci. 98, 1341-1363.

Wang, S.-L., Chen, Y., Charreau, J., Wei, D.-T., Jia, D., 2013. Tectono-stratigraphic history of the southern Junggar basin: seismic profiling evidences. Terra Nova 25 , 490-495.

Wei, S.N., Cheng, J.F., Yu, D.B., Zhu, Y.F., 2011. Petrology and SHRIMP zircon ages of intrusive body III in Baogutu area, Xinjiang. Earth Sci. Front. 18, 212-222 (in Chinese with English abstract).

Wilhem, C., Windley, B.F., Stampfli, G.M., 2012. The Altaids of Central Asia: a tectonic and evolutionary innovative review. Earth Sci. Rev. 113, 303-341.

Windley, B.F., Alexeiev, D., Xiao, W., Kröner, A., Badarch, G., 2007. Tectonic models for the accretion of the Central Asion Orogenic Belt. J. Geol. Soc. Lond. 164, 31-47.

Xiao, W., Han, C., Yuan, C., Sun, M., Lin, S., Chen, H., Li, Z., Li, J., Sun, S., 2008. Middle Cambrian to Permian subduction-related accretionary orogenesis of Northern Xinjiang, NW China: implications for the tectonic evolution of central Asia. J. Asian Earth Sci. 32, 102-117

Xiao, W.. Huang, B.. Han, C., Sun, S., Li, J., 2010. A review of the western part of the Altaids: a key to understanding the architecture of accretionary orogens. Gondwana Res. 18, 253-273.

Xiao, W., Windley, F., Allen, B., Han, C., 2013. Paleozoic multiple accretionary and collisional tectonics of the Chinese Tianshan orogenic collage. Gondwana Res. 23, 1316-1341.

Yang, W., Jolivet, M., Dupont-Nivet, G., Guo, Z., Zhang, Z., Wu, C., 2013. Source to sink relations between theTian Shan and Junggar Basin (northwest China) from Late Palaeozoic to Quaternary: evidence from detrital U-Pb zircon geochronology. Basin Res. 25, 219-240.

Yang, W., Jolivet, M., Dupont-Nivet, G., Guo, Z., 2014a. Mesozoic-Cenozoic tectonic evolution of southwestern Tian Shan: evidence from detrital zircon U/Pb and apatite fission track ages of the Ulugqat area, Northwest China. Gondwana Res. 26, 986-1008.

Yang, G., Li, Y., Safonova, I., Yi, S., Tong, L., Seltmann, R., 2014b. Early Carboniferous volcanic rocks of West Junggar in the western Central Asian Orogenic Belt: implications for a supra-subduction system. Int. Geol. Rev. 56, 823-844.

Yang, Y.-T., Song, C.-C., He, S., 2015. Jurassic tectonostratigraphic evolution of the Junggar Basin, NW China: a record of Mesozoic intraplate deformation in Central Asia. Tectonics 34, 86-115.

Yin, J., Yuan, C., Sun, M., Long, X., Zhao, G., Wong, K.P., Geng, H., Cai, K., 2010. Late Carboniferous high-Mg dioritic dikes in Western Junggar, NW China: geochemical features, petrogenesis and tectonic implications. Gondwana Res. 17, 145-152.

Yin, J., Long, X., Yuan, C., Sun, M., Zhao, G., Geng, H., 2013. A Late Carboniferous-Early Permian slab window in the West Junggar of NW China: geochronological and geochemical evidence from mafic to intermediate dikes. Lithos 175-176, 146-162.

Yu, S., Chen, W., Evans, N.J., McInnes, B.I.A., Yin, J., Sun, J., Li, J., Zhang, B., 2014. Cenozoic uplift, exhumation and deformation in het north Kuqa Depression, China as constrained by (U-Th)/He thermochronometry. Tectonophysics 630, 166-182.

Yuan, W.-M., Carter, A., Dong, J.-O., Bao, Z., An, Y., Guo, Z., 2006. Mesozoic-Tertiary exhumation history of the Altai Mountains, northern Xinjiang, China: new constraints from apatite fission track data. Tectonophysics 412, 183-193.

Zhang, Z.H., Mao, J.W., Du, A.D., Pirajno, F., Wang, Z.L., Chai, F.M., Zhang, Z.C., Yang, J.M., 2008. Re-Os dating of two Cu-Ni sulfide deposits in northern Xinjiang, NW China and its geological significance. J. Asian Earth Sci. 32, 204-217.

Zhao, L., He, G., 2013. Tectonic entities connection between West Junggar (NW China) and East Kazakhstan. J. Asian Earth Sci. 72, 25-32.

Zhou, T., Yuan, F., Fan, Y., Zhang, D., Cooke, D., Zhao, G., 2008. Granites in the Sawuer region of the west Junggar, Xinjiang Province, China: geochronological and geochemical characteristics and their geodynamic significance. Lithos 106, 191-206.

Zhu, Y.F., He, G.Q., An, F., 2007. Geological evolution and metallogeny in the core part of the Central Asian metallogenic domain. Geol. Bull. China 26, 1167-1177.

Zorin, Y.A., 1999. Geodynamics of the western part of the Mongolia-Okhotsk collisional belt, Trans-Baikal region (Russia) and Mongolia. Tectonophysics 306, 33-56. 